\title{
Does institutional quality condition the effect of bank regulations and supervision on bank stability? Evidence from emerging and developing economies
}

\author{
Theodora Bermpei ${ }^{1}$, Antonios Kalyvas ${ }^{2}$ and Thanh Cong Nguyen ${ }^{3}$
}

\begin{abstract}
Does institutional quality enhance or weaken the effect of bank regulations and supervision on bank stability? We use a sample of around 1,050 commercial banks from 69 emerging and developing economies over the 2004-2013 period and show that the answer to this question depends on the type of institutional quality and on the type of bank regulation. Political stability strengthens the positive effect of capital regulation and activities restrictions on bank stability as measured by the z-score. Control of corruption also enhances the positive effect of activities restrictions on stability. On the other hand, the positive effect of capital regulation and private monitoring on stability subdues when good quality institutions that induce loan repayment, such as strong creditor rights and the rule of law, are present. Finally, we do not find strong evidence that the negative effect of supervisory power on bank stability is conditioned by institutional quality. In further analysis, we disaggregate the z-score measure and find that institutional quality conditions the effect of bank regulations on stability more by affecting profit stability and profitability rather than by influencing capitalisation. These findings could be useful for bank regulators in emerging and developing economies in the light of the implementation of the Basel III accord.
\end{abstract}

Keywords: Bank Stability, Bank Regulation and Supervision, Institutional Quality, Emerging and Developing Economies

JEL: G21, G28

\footnotetext{
${ }^{1}$ Essex Business School, University of Essex, Wivenhoe Park, Colchester, CO4 3SQ, UK. E-mail: t.bermpei@essex.ac.uk

${ }^{2}$ Corresponding author, Department of Banking and Finance, Southampton Business School, University of Southampton, Building 2, 12 University Road, Southampton, SO17 1BJ, UK. E-mail: n.a.kalyvas@soton.ac.uk

${ }^{3}$ School of Business and Economics, Loughborough University, LE11 3TU, UK. E-mail: T.C.Nguyen@lboro.ac.uk
} 


\section{Introduction}

The effect of bank regulations and supervision on bank stability is an ongoing debate for both academics and policymakers. Several empirical studies find inconclusive results about the effect of different types of bank regulation on stability (e.g. Barth et al., 2004; Agoraki et al., 2011; Anginer et al., 2014). A source of such inconclusiveness is that various factors could condition this relationship. The empirical evidence shows that the effect of bank regulations and supervision on stability could depend on corporate governance (Laeven and Levine, 2009), bank industry characteristics (Agoraki et al., 2011) and the macroeconomic environment (Klomp and Haan, 2015). For this reason, Delis et al. (2012) stress the importance of identifying sources of heterogeneity concerning the effect of different types of bank regulation on bank stability. We follow this suggestion and investigate if institutional quality conditions the effect of bank regulation and supervision on bank stability.

Institutional quality could condition the effect of bank regulations and supervision on stability because it could enhance the implementation capacity of regulators. Such capacity is of importance in the banking sector due to the increasing complexity of bank regulations through the Basel I, II and III accords over the years (Haldane and Neumann, 2017). Institutional quality, by improving implementation capacity, could have a complementary relationship with bank regulations and supervision concerning their effect on stability. We name this hypothesis as the "institutional quality-regulation enforcement" hypothesis. We identify three institutional quality characteristics that could enhance regulatory implementation capacity. These are political stability, the control of corruption and the rule of law. Theoretical models and empirical evidence from the economics and the political economy literature show that these three types of institutional quality induce regulatory enforcement (Knack and Keefer, 1995; Damania et al., 2004; Acemoglu and Verdier, 2000; Jiang and Nie, 2014; Oliva, 2015).

However, institutional quality could instead have a substitution relationship with bank regulations and supervision because the former could induce the efficient functioning of the lending market. Good institutional quality in terms of political stability, control of corruption and the rule of law, could reduce adverse selection and borrower moral hazard, improve the lending terms and thus improve loan repayment (Bae and Goyal, 2009; Schiantarelli et al., 2016). This, in turn, could moderate the effect of bank regulation and supervision on bank stability. For example, capital regulation, which forces banks to hold more capital in order to absorb potential losses, could be less useful for bank stability in an institutional setting that induces loan repayment and thus limits bank losses. We name the hypothesis that suggests a substitution relationship between institutional quality and bank regulation and supervision 
concerning bank stability as the "institutional quality-loan repayment" hypothesis. Moreover, we expand this hypothesis to two additional institutional quality characteristics. These are the strength of creditor rights and credit information sharing. These two institutional arrangements could decrease the information asymmetry between lenders and borrowers and thus could be conducive to loan repayment (Houston et al., 2010).

A suitable testing ground for our two hypotheses are the emerging and developing economies. To begin with, emerging and developing economies exhibit a high degree of cross-country variation both in terms of bank regulation and supervision and in terms of institutional quality. Additionally, the regulation implementation capacity of many emerging and developing economies is weak (Chong et al., 2014). Thus, institutions that could enhance regulatory enforcement could be important for the effect of bank regulations on stability. Furthermore, these countries exhibit high information asymmetry between lenders and borrowers (Fosu, 2014). Hence, institutions that induce loan repayment could be essential for bank stability. The above points suggest that focusing on emerging and developing economies is interesting in terms of investigating the conditioning effects of institutional quality on the relationship between bank regulations and supervision and bank stability both through the "institutional quality-regulation enforcement" hypothesis and through the "institutional quality-loan repayment" hypothesis.

To this end, we use a dataset of approximately 1,050 commercial banks from 69 emerging and developing economies over the 2004-2013 period. Regarding bank regulations and supervision, we follow previous studies (e.g. Hoque et al., 2015) and focus on i) capital requirements regulation, ii) official supervisory power, iii) private monitoring, and iv) activities restrictions. We source comparable indices for these types of bank regulations from Barth et al., (2013) ${ }^{4}$. Furthermore, we source institutional quality indicators from the World Governance Indicators and the Doing Business projects of the World Bank. As in previous studies (e.g Houston et al, 2010; Beck et al., 2013), we measure bank stability in terms of z-score and provide a rich set of findings. We obtain these findings from models that employ the two-step system generalized method of moments (GMM) estimator (Arellano and Bover, 1995; Blundell and Bond, 1998) which takes into account both the persistence of bank stability and the potential endogeneity between bank regulations and supervision with bank stability.

\footnotetext{
${ }^{4}$ The dataset on bank regulation and supervision of Barth et al. (2013) represents the most diligent effort to date in order to standardise and render comparable, both across time and across countries, indices of bank regulation and supervision. This dataset builds on the different bank regulatory survey waves by the World Bank since 1999.
} 
Overall, we find that institutional quality conditions the relationship of bank regulation and supervision with bank stability but not in a uniform way. Political stability and control of corruption emerge as the institutional quality characteristics that condition the effect of bank regulations and supervision on stability more in line with the "institutional quality-regulation enforcement" hypothesis. We find that the positive effect of capital regulation and activities restrictions on bank stability strengthens in the presence of higher political stability. Furthermore, control of corruption enhances the positive effect of activities restriction on bank stability. On the other hand, institutional characteristics that are highly conducive to loan repayment, such as strong creditor rights and the rule of law, condition the effect of bank regulation and supervision on stability more in line with the "institutional-quality-loan repayment" hypothesis. The empirical findings show that the positive effect of capital regulation and private monitoring on bank stability subdues at higher levels of creditor rights and rule of law respectively. Finally, we find only limited evidence that institutional quality conditions the negative effect of official supervisory power on bank stability. In further analysis, we disaggregate the z-score to its components and show that institutional quality conditions the effect of bank regulations on stability more by affecting bank profit stability and profitability rather than by influencing bank capitalisation. Most of these results are robust in models that employ alternative institutional quality variables and in models that use institutional quality measures that we derive from a principal component analysis.

This study contributes to the literature in four ways. Firstly, we add to the literature that examines the effects of bank regulations and supervision on bank stability (e.g. Hoque et al., 2015). We show that institutional quality plays an important role in explaining the crosscountry variation of the effect of bank regulations on stability. Thus, this study improves our understanding of the association between bank regulations and stability and informs the inconclusive yet debate about this relationship. Secondly, we employ a rich set of disaggregated measures of institutional quality. This enables us to identify the specific institutional quality characteristics that have a complementary or a substitution relationship with different types of bank regulations concerning the effect of the latter on bank stability. The use of disaggregated measures of institutional quality is also useful in terms of informing policy in a more focused manner. Therefore, we also add to the limited research that uses aggregate indicators to investigate if institutional factors influence the effect of bank regulations on stability (Klomp and Haan, 2014). Thirdly, by focusing on emerging and developing economies, we also add to the literature that examines the determinants of bank stability in these countries (e.g. Drakos et al, 2016). Emerging and developing economies are 
the drivers of global growth and their banking systems represent a growing part of the global banking sector. Hence, examining the factors that could contribute to bank stability in these countries is of increasing importance. Finally, by providing empirical evidence from the banking sector, we also contribute to the wider economics literature that investigates the conditioning effects of institutional quality on the relationship between regulations and economic outcomes (e.g. Dreher and Gassebner 2013; Jiang and Nie, 2014; Oliva, 2015).

The rest of the paper is structured as follows: section 2 presents some theoretical considerations and develops the hypotheses, section 3 presents the data and the methods, section 4 reports and discusses the results, whilst the final section offers some concluding remarks together with some policy implications.

\section{Theoretical Considerations and Hypotheses Development}

In this section, we first provide a brief overview of the mechanisms through which the main types of bank regulation and supervision could affect bank stability and present the main findings from previous empirical research. Then, we develop the hypotheses about the potential conditioning effect of institutional quality on the relationship between bank regulation and supervision and bank stability.

\subsection{Overview of the Relationship between Bank Regulation and Supervision with Bank Stability}

Capital regulation could benefit bank stability by encouraging banks to hold higher capital buffers and enhancing their loss absorption capacity (Dagher et al., 2016). Some studies provide empirical evidence that stringent capital requirements decrease non-performing loans and bank risk (Agoraki et al., 2011; Tan and Floros, 2013). On the other hand, capital regulation could hamper bank stability by decreasing the motivation of lenders to monitor loans (Kopecky and VanHoose, 2006). Recent empirical findings show that capital regulation increases non-performing loans (Osei-Assibey and Asenso, 2015).

Official supervisory power could increase bank stability by allowing regulators to prevent and correct banks' problems (Anginer and Demirguc-Kunt, 2014). The beneficial effect of supervisory power on bank stability assumes the "public interest view" of supervision (Barth et al, 2008). This view posits that regulatory officials act in the interest of the public and promote bank stability. In support of this view, some empirical studies show that supervisory power benefits bank stability through better loan quality and lower moral hazard (Agoraki et al., 2011;

Shehzad and Haan, 2015). However, a strong supervisor could exploit its power and influence 
bank credit allocation in order to reap private gains (Beck et al., 2006). This could result in lower loan quality and thus a decrease in bank stability (Beltratti and Stulz, 2012). The potential negative effect of supervisory power on bank stability assumes the "private interest view” of supervision (Barth et al, 2008). This view suggests that supervisors target to maximise their own welfare.

Regulation that enhances the private monitoring of banks from depositors, debt holders, and equity holders could benefit bank stability by improving market discipline and decreasing risktaking incentives and moral hazard (Anginer et al., 2014). On the other hand, the higher disclosure requirements that private monitoring mandates might lower the incentive of bank creditors to roll over their funds in the case of a negative signal (Bouvard et al., 2015). Banks could try to compensate for this by increasing their risk.

Finally, activities restrictions could improve bank stability by limiting the engagement of banks in non-interest income activities. Such activities are particularly risky because they exhibit high earnings volatility (Demirguc-Kunt and Huizinga, 2010) and thus could hamper bank stability (DeYoung and Torna, 2013). Conversely, activities restrictions could decrease bank stability by limiting diversification benefits (Kohler, 2015).

The above discussion suggests that the effect of bank regulation and supervision on bank stability could be either positive or negative. We posit that the relative strength of the individual, positive or negative, effect of bank regulation and supervision on bank stability could be a function of a country's institutional quality. This means that institutional quality could condition the effect of bank regulation and supervision on bank stability. In the next part of section 2, we formulate two such conditioning hypotheses.

\subsection{The Conditioning Effect of Institutional Quality on the Relationship between Bank Regulation and Supervision with Bank Stability}

\subsubsection{The "Institutional Quality-Regulation Enforcement" Hypothesis}

The mere existence of a regulation on paper does not necessarily imply its application in practice. We hypothesise that institutional quality in terms of political stability, the rule of law and control of corruption could enhance the implementation capacity of a country's regulators. Therefore, institutional quality could complement bank regulation and supervision. We name this potential complementary relationship as the "institutional quality-regulation enforcement" hypothesis. 
Political stability improves the ability and the consistency of the regulatory enforcement mechanisms (Knack and Keefer, 1995; Roe and Siegel, 2011). Damania et al., (2004) provide empirical evidence that political instability weakens the institutions that are necessary to monitor and enforce regulatory compliance. Therefore, a channel through which the lack of political stability could diminish the implementation capacity of bank regulators could be its harmful effect on the operational capability of the latter. Through another channel, economic agents, such as banks, could be less likely to comply with regulations in countries with low political stability because of the uncertainty about regulation and government policy that this lack of political stability implies (Baker et al., 2015).

The role of control of corruption is also important in terms of enforcement of regulations. Theoretical models in the legal and economic literature provide strong support to the concept that corruption reduces regulatory compliance (e.g. Acemoglu and Verdier, 2000; Aidt, 2003). In support of these theoretical predictions, many studies provide empirical evidence that firms operating in a corrupt environment attempt to circumvent regulations through bribery (see e.g. Mendoza et al., 2015; Oliva, 2015). Therefore, one could argue that an environment of high control of corruption promotes the implementation and observance of regulations.

The rule of law, which is a measure of perceptions of law observance and judicial efficiency, could also induce regulatory enforcement. Berger and Udell (2006) point out the complementary relationship of regulations with the judicial environment. Several studies provide empirical evidence that higher levels of rule of law and judicial efficiency enhance regulatory enforcement (see e.g. Caballero et al., 2013; Daher, 2017). The channels through which higher rule of law and judicial efficiency could lead to stronger regulatory enforcement is through the higher probability of detection of irregularities (Olken, 2007) and an increase in the probability of prosecution and conviction (Alt and Lassen, 2014).

Based on the above discussion, we formulate the "institutional quality-regulation enforcement" hypothesis as follows:

\section{H.1: Institutional quality could enhance the effect of bank regulations and supervision on bank stability.}

\subsubsection{The "Institutional Quality-Loan Repayment" Hypothesis}

We also hypothesise that institutional quality could contribute to a well-functioning lending market by improving the lending terms, reducing adverse selection and borrower moral hazard and increasing the probability of loan repayment. Hence, institutional quality could be a 
substitute for bank regulation and supervision. We name this potential substitution relationship as the "institutional quality-loan repayment" hypothesis.

Political stability could improve the lending terms and therefore reduce borrower moral hazard and decrease loan defaults. Francis et al. (2014) provide evidence from the syndicated loan market that political uncertainty increases the cost of bank loans. Similarly, Bradley et al. (2016) find that policy risk increases the cost of debt of firms. Furthermore, strong political institutions could have a positive effect on firm transparency and disclosure (Bushman et al. 2004). This could improve the quantity and the accuracy of the information that banks have on borrowers. Consequently, banks could reduce adverse selection and price loans more efficiently.

Control of corruption could also promote efficient lending and increase the probability of loan repayment. One channel through which control of corruption could achieve this is by reducing lending corruption, which is an important reason of loan losses in many countries (Beck et al. 2006; Akins et al. 2017). Additionally, Bae and Goyal (2009) provide empirical evidence that loan spreads are higher in countries with higher levels of corruption. One explanation is that corruption could restrain the financial performance of borrower firms (Hanousek et al., 2017) and thus render loan losses more probable. Furthermore, corruption could undermine the institutions that ensure the enforcement of loan contracts and thus increase borrower moral hazard (Weill, 2011).

The latter point highlights the importance of the rule of law, especially as far as concerns a competent judiciary, for the efficient operation of the lending market. Laeven and Majnoni (2005) show that judicial inefficiency increases loan spreads and thus renders loan repayment harder. Furthermore, Bae and Goyal (2009) find that in the case of a loan default, an inefficient judicial system reduces the recovery rate and increases the time needed to repossess collateral. This could increase the moral hazard of borrowers. In the presence of a slow and inefficient judicial process, opportunistic borrowers might choose to default because the loan recovery costs might not make economic sense for the lender (Jappelli et al., 2005; Schiantarelli et al., 2016).

There are two additional institutional quality characteristics relevant to the "institutional quality-loan repayment hypothesis". These are the strength of creditor rights and credit information sharing. These institutional arrangements reduce the information asymmetry between lenders and borrowers and could induce loan repayment. Thus, they could have a substitution relationship with bank regulation and supervision. Creditor rights could reduce adverse selection and improve loan screening efficiency by facilitating the use of collateral and 
enhancing its signaling function, (Bester, 1985). Creditor rights could also reduce borrowers' moral hazard and loan losses by enabling banks to force loan repayment (Acharya et al., 2011; Fang et al., 2014). Information sharing, by providing information on the past behavior of borrowers, could enable loan screening and thus reduce adverse selection (Dierkes et al., 2013). Information sharing could also reduce borrowers' moral hazard by incentivising them to avoid a loan default that would blacklist them and exclude them from future access to finance (Padilla and Pagano, 2000). Several studies provide empirical evidence that information sharing improves loan repayment and bank stability (see e.g. Houston et al., 2010).

Based on the above discussion, we formulate the "institutional quality-loan repayment" hypothesis as follows:

\section{H.2: Institutional quality could moderate the effect of bank regulations and supervision on} bank stability.

Activities restrictions could provide an exception to the above hypothesis. This type of regulation reduces the possibility that banks could diversify away from the traditional lending market. Therefore, in the case that the individual effect of activities restrictions on bank stability is positive, the presence of good institutions that promote loan repayment could further enhance this impact. In this case, the "institutional quality-loan repayment" channel suggests a complementary relationship between activities restrictions and institutions. Conversely, if the individual effect of activities restrictions on bank stability is negative, then good institutions, by inducing loan repayment, could lessen such a negative impact. In such a case, the "institutional quality-loan repayment" channel posits a substitution relationship between activities restrictions regulation and institutions. Thus, for activities restrictions, we modify hypothesis $H .2$ to hypothesis $H .3^{5}$ :

H.3: Institutional quality could enhance (moderate) the positive (negative) effect of activities restrictions regulation on bank stability.

\footnotetext{
${ }^{5}$ The Figures A1 and A2 of the appendix illustrate the theoretical framework of the hypotheses (Figure A1 for the hypothesis H.1 in relation to the hypothesis H.2 and Figure A2 for the hypothesis H.1 in relation to the hypothesis H.3).
} 


\section{Data and Methods}

\subsection{Data}

\subsubsection{Sample}

The sample of the study is an unbalanced panel of 1,052 commercial banks operating in 69 emerging and developing economies over the 2004-2013 period that comprises 5,854 bankyear observations ${ }^{6}$. We follow several studies and focus the analysis on commercial banks for which lending is their main business line (e.g. Delis, 2012; Laeven et al., 2016). Furthermore, regulatory indices and bank stability theories tend to focus on the operations of commercial banks and a homogenous sample in terms of bank types improves comparability (Pasiouras et al., 2009). To classify countries as emerging or developing we use the 2013 version of the World Bank income classification (Delis, 2012). More specifically, we define countries as emerging or developing if they belong to the middle or the low-income categories of the World Bank classification. Finally, the period of the analysis, 2004-2013, reflects the data availability of some of the explanatory variables ${ }^{7}$.

\subsubsection{Measuring bank stability}

We employ z-score as a measure of bank stability. This is the standard bank stability measure in most empirical studies (e.g. Houston et al., 2010; Ashraf, 2017). The z-score is calculated by the sum of a bank's return on assets (ROA) and the equity-to-assets ratio (EQAS) over the standard deviation of its return on assets (SDROA). Specifically, z-score = $(\mathrm{EQAS}+\mathrm{ROA}) / \mathrm{SDROA}^{8}$. The z-score of a bank is its distance from insolvency as it represents

\footnotetext{
${ }^{6}$ See Table A1 of the appendix for the countries included in the study. The initial sample was 1,156 banks from 69 countries. However, due to data availability for some banks the final sample consists of 1,052 banks.

${ }^{7}$ For example, some of the institutional quality measures such as creditor right and information sharing are available in a consistent manner (i.e. same data methodology) from the World Bank for the 2004-2013 period.

${ }^{8}$ We have also performed estimations that employ as a measure of bank stability the adjusted z-score which is based on the Return on Equity (ROE). We obtain similar findings when we use this alternative bank stability measure.
} 
the number of standard deviations that a bank's ROA has to fall for the bank to become insolvent (Demirguc-Kunt and Huizinga, 2010). We calculate the standard deviation of ROA using three-year rolling time windows (Beck et al, 2013). This method avoids that the standard deviation of ROA is calculated over different window lengths for different banks. Furthermore, we use the natural logarithm of z-score (lnz-score) to smooth out high values of z-scores as they are highly skewed (Beck et al. 2013). To estimate z-scores we source bankspecific data from Bankscope.

\subsubsection{Bank regulations and Supervision}

To provide a comprehensive view of bank regulation and supervision, we source regulatory variables from the three most recent global surveys of Barth et al. (2013) in, 2002, 2006, and 2011. Since the bank regulation and supervision indices change slowly over time, we follow the literature and use the previously available regulatory survey data until a new survey becomes available (Anginer et al., 2014). Specifically, we assign the 2002 survey data for the 2004-2005 period, the 2006 survey data for the 2006-2010 period and the 2011 survey data for the 2011- 2013 period. The four-bank regulation and supervision variables we employ are the following:

Capital regulations $(C S)$ : This index concerns regulations that require banks to hold a minimum rate of capital to protect banks from insolvency. It measures the stringency of capital regulations by examining whether banks have flexible minimum capital-asset ratios under different types of risks, and how banks deduct market value losses from capital before having the pre-determined minimum capital adequacy. The index also considers the initial capital stringency by determining whether some sources of funds used to raise the initial disbursement of capital are allowed. The capital regulations index can take values between 0-10, where higher values represent more stringency.

Official supervisory power $(O P)$ : Measures the extent to which supervisory authorities have the power to access banks' information and whether they can take specific actions to prevent or address problems such as fraud and insider abuse. The official supervisory power index ranges from 0-14 and higher values indicate more power.

Private monitoring $(P M)$ : This index refers to the degree to which regulatory and supervisory policies provide private investors the power to monitor banks' operation and governance. The private monitoring index investigates whether banks have a certified external audit and if the 10 largest banks are rated by international and domestic credit rating agencies. The index also 
considers bank regulations relating to explicit deposit insurance, the compensation to customers in the case of bankruptcy, and bank accounting in terms of unpaid interest, nonperforming loans, and consolidated financial statements. This index can take values between 0 and 12 with higher values representing a higher level of private monitoring.

Activities Restrictions (RES): This index measures the extent to which bank regulations restrict banks from engaging in securities, insurance, and real estate activities. In particular, the index considers securities activities in terms of securities underwriting, brokerage, and dealing. Insurance activities refer to the extent to which banks may underwrite and sell insurance. Finally, real estate activities refer to the extent to which banks could engage in real estate investment, development, and management. This index ranges from 3-12 with higher values denoting restrictions that are more stringent.

In Table 1 we provide more detailed and technical definitions of the bank regulation and supervision indices, as well as details for the other variables we use in this study.

Table 1

\subsubsection{Institutional quality}

We source the political stability, control of corruption and the rule of law indicators from the Worldwide Governance Indicators (WGI) project of the World Bank. The definitions of these institutional quality variables are the following:

Political stability (POL): It measures perceptions of the likelihood that the government will be destabilized or overthrown by unconstitutional or violent means, including politically motivated violence and terrorism. The values of this index range from -2.5 to +2.5 with higher values implying a more stable political environment.

Control of corruption (COR): This is a measure of the perceptions of the extent to which public power is exercised for private gain, including both petty and grand forms of corruption. The index ranges from -2.5 to +2.5 with higher values implying better control of corruption.

Rule of law $(R L)$ : This index refers to the perceptions of the extent to which agents have confidence in and abide by the rules of society, and in particular the quality of contract enforcement, the police, and the courts, as well as the likelihood of crime and violence. The rule of law index ranges from -2.5 to +2.5 with higher value implying stronger rule of law. Furthermore, we source the creditor rights $(C R)$ and information sharing (IS) indices from the Doing Business project of the World Bank. The creditor rights index measures the extent to which collateral and bankruptcy legislation defends the rights of lenders. This index ranges from 0 to 10 with higher values implying stronger creditor protection. The information sharing 
index measures rules and practices affecting the coverage, scope, and accessibility of credit information available through either a credit bureau or a credit registry. The range of this index is from 0 to 6 with higher values denoting a higher availability of credit information.

\subsubsection{Control variables}

We also employ several control variables that we draw from the bank stability literature. In terms of bank-specific controls, we use the natural logarithm of total assets (lnTA) to proxy for bank size and the ratio of loan loss provisions over total loans (LPPL) as a proxy for the quality of the loan portfolio (Barakat and Hussainey, 2013). We also employ the ratio of equity to total assets (EQAS) to control for the monitoring of the management from the equity holders and the loan to assets ratio (LOAN) to capture the asset side of the balance sheet (Beltratti and Stulz, 2012; Barth et al., 2013). Finally, to control for bank growth we follow Demirguc Kunt and Huizinga (2010) and use the real (i.e. inflation-adjusted) growth rate of a bank's assets (ASTGR). We source the bank-specific variables from Bankscope.

In terms of country-level controls, we employ both bank industry and macroeconomic variables. In order to proxy for bank industry concentration, we use loan data and measure the Herfindahl-Hirschman Index (HHI). We use the following equation to estimate the HHI index: $H H I=\sum_{i=1}^{n}\left(M S_{i}\right)^{2}$. In this equation, MS is the loan market share of the $i_{t h}$ bank and $n$ is the number of banks in a market (i.e. country). Thus, the HHI index places emphasis on banks with higher market share by assigning greater weight on them compared to banks with lower market share. Furthermore, to proxy for the corporate governance quality of a country's banks we employ the corporate board efficacy indicator (CGOV) that we source from the Global Competitiveness Report of the World Economic Forum (WEF). This indicator ranges from 1 to 7 with higher values denoting a higher representation of outside shareholders and investors on the board. Higher board efficacy could improve bank stability because outside shareholders and investors may alleviate the opportunistic behaviour of bank managers. With respect to macroeconomic control variables, we employ the inflation rate (INF) as a proxy for monetary instability (Beck et al., 2006) and the GDP growth rate as a proxy for fluctuations in the economic activity (Agoraki et al., 2011). Furthermore, we use the natural logarithm of GDP per capita (GDPC) in purchasing power parity (PPP) terms to measure the overall level of economic development (Barth et al., 2013). We source the macroeconomic variables from the 
World Development Indicators (WDI) database of the World Bank. In Table 2 we provide some summary statistics of the variables we use in the study'.

Table 2

\subsection{Methods}

There are two important concerns that we need to take into account before selecting an appropriate identification strategy. The first is the potential persistence of bank stability (Agoraki et al., 2011). The second is the potential endogeneity of bank stability with the bankspecific and the bank regulation and supervision variables (Delis and Staikouras, 2011). For these two reasons, we opt to estimate dynamic panel models using the two-step system generalized method of moments (GMM) estimator as advanced by Arellano and Bover (1995) and Blundell and Bond (1998) with robust standard errors (Windmeijer, 2005). More specifically, we provide estimations of the following model (1):

$\operatorname{lnZ}$ SCORE $_{i, t}=\alpha_{0}+\beta_{1} \operatorname{lnZ} Z-S C O R E_{i, t-1}+\beta_{2} R E G_{j, t}+\beta_{3} I N S T_{j, t}+\beta_{4} R_{E G} G_{j, t} x \operatorname{INST}_{j, t}+\beta_{5} B_{A N K_{i, t}}$

$+\beta_{6} \operatorname{COUNTRY}_{j, t}+\theta_{j}+\lambda_{\mathrm{t}}+\mu_{i}+\varepsilon_{i, t}$

In equation (1), $i, j, t$ stand for bank, country and year respectively. The variable $\ln Z-S C O R E_{i, t}$ stands for the natural logarithm of the bank stability measure while $R E G_{j, t}$ stands for the vector of bank regulation and supervision variables. Furthermore, $I N S T_{j, t}$ stands for the vector of institutional quality variables. Additionally, $B A N K_{i, t}$ stands for the vector of the bank-specific control variables and $\operatorname{COUNTRY}_{j, t}$ is a vector of the country-specific control variables. Finally, $\theta_{j}$ represents country effects, $\lambda_{t}$ is a set of year effects, $\mu_{i}$ is a bank-specific effect and $\varepsilon_{i, t}$ is the error term.

The inclusion of the lagged dependent variable as an explanatory variable in the equation (1) accounts for the potential persistence of bank stability. Another virtue of the two-step system GMM estimator is that we can treat some of the explanatory variables as endogenous with the use of appropriate instruments. In our estimations we treat as endogenous the lagged dependent variable, $\operatorname{lnZ} \mathrm{SCORE}_{i, t-1}$, as it is the standard in the literature. Furthermore, we follow previous empirical research (Delis and Staikouras, 2011, Delis 2012) ${ }^{10}$ and treat as endogenous the bank regulation variables (activities restrictions, capital requirements regulation, supervisory power, and private monitoring) as well as the bank-specific controls (size, the loan to assets ratio, the

\footnotetext{
${ }^{9}$ A correlation matrix of the variables of the study is available in Table A2 of the appendix.

${ }^{10}$ Delis and Staikouras (2011) provide a detailed discussion on the issue of endogeneity between bank stability and bank regulation. In short, regulators could be motivated to change bank regulation and supervision when they observe excessive risks in the banking sector.
} 
equity to assets ratio, the loan loss provisions to assets ratio and bank asset growth). We also treat as endogenous some country-level controls that relate to the banking sector. Specifically, we treat as endogenous the creditor rights and the credit information-sharing indices ${ }^{11}$ as well as the bank industry concentration ( $\mathrm{HHI}$ ) and the corporate governance quality (CGOV) measures. Treating the above variables as endogenous suggests that we can use their second and longer lags as instruments (Blundell and Bond, 1998; Bond, 2002).

Finally, we treat the rest of the institutional quality variables (political stability, control of corruption and the rule of law) and the macroeconomic controls (inflation, GDP growth and GDP per capita) as predetermined (Delis and Staikouras, 2011, Delis, 2012). This means that banks note the state of the economy and institutional quality in each year period and adjust their strategy accordingly. For the variables that enter the dynamic panel models as predetermined their first and longer lags can be used as instruments. The results of the twostep system GMM estimator are verified by Hansen's $J$ test for instrument validity and the second-order autocorrelation of the error terms test, AR2, as introduced by Arellano and Bond (1991).

\section{Empirical Findings and Discussion}

\subsection{Main Empirical Findings}

\subsubsection{Capital Regulation and Institutional Quality}

The models 1-5 of Table 3 provide the results of the dynamic panel estimations that relate to the conditioning effect of institutional quality on the relationship between capital regulation and bank stability ${ }^{12}$.

Table 3

These models show that the lag of the dependent variable, the natural log of the z-score, carries a positive and significant at the $1 \%$ level coefficient. This denotes the persistence of bank stability and justifies the use of dynamic panel analysis in this study. In models 1-5 of Table 3, we find that the individual effect of stringent capital regulation (CS) on bank stability is positive and in some cases also significant at conventional statistical levels. This result is in

\footnotetext{
${ }^{11}$ Although creditor rights and credit information sharing are not bank regulation and supervision variables, they are still largely specific to the banking sector and could be endogenous with measures of bank stability and performance. For example, banks may decide, in order to improve their performance and stability, to increase credit information sharing through private credit bureaus. There is a stream in the literature that explains how credit information sharing could arise endogenously (see e.g. Padilla and Pagano, 1997).

${ }^{12}$ Some observations are lost from the total sample because of the availability of some of the right hand-side variables and the use of lagged values in the dynamic panel models.
} 
line with studies that find that capital regulation, by increasing the loss absorption capacity of banks, decreases bank risk (Agoraki et al., 2011; Tan and Floros, 2013).

Concerning the conditioning effects of institutional quality, we find in model 1 of Table 3 that the interaction term between capital requirements regulation (CS) and political stability (PS) is positive and significant at the $1 \%$ level. Hence, the positive effect of capital regulation on bank stability strengthens at higher levels of political stability. This suggests a complementary relationship between institutional quality in terms of political stability and bank regulation in terms of capital stringency. Therefore, this finding provides empirical evidence in support of the H.1 "institutional quality-regulation enforcement" hypothesis. Political stability could induce the enforcement of regulations through ensuring the consistency and the implementation capacity of the regulatory mechanisms (Roe and Siegel, 2011). However, the other two institutional quality characteristics that could be relevant to the H.1 "institutional qualityregulation enforcement" hypothesis, the control of corruption (CCOR) and the rule law (RL), do not interact significantly with the capital regulation (CS) variable (see models 2 and 3 of Table 3). A potential explanation is that the control of corruption and the rule of law could function also as substitutes of capital regulation by improving lending efficiency and the probability of loan repayment (Laeven and Majnoni, 2005; Bae and Goyal, 2009). Therefore, the role that these two institutional characteristics play in the "institutional quality-loan repayment" channel could neutralise their potential beneficial effect on bank regulation enforcement, through the "institutional quality-regulation enforcement channel", and viceversa.

Turning to the interaction term of capital regulation (CS) with creditor rights (CR), we find that it enters model 4 of Table 3 with a negative and significant, at the $1 \%$ level, coefficient. This suggests that the positive individual effect of stringent capital regulation (CS) on bank stability subdues at higher levels of creditor rights (CR). This finding implies a substitution relationship between capital regulation (CS) and creditor rights (CR). Thus, this result is consistent with hypothesis $H .2$, which posits that institutional quality could moderate the individual effect of bank regulation on bank stability. In line with the "institutional quality-loan repayment" view, when banks can grab collateral in case of loan defaults and thus can limit their losses, then the importance of the loss-absorbing capacity of banks due to stringent capital regulation subdues. Finally, in model 5 of Table 3, the coefficient of the interaction between information sharing (IS) and capital regulation (CS) is not significantly different from zero.

\subsubsection{Supervisory Power and Institutional Quality}


The models 6-10 of Table 3 provide the findings of the interaction terms between official supervisory power (OP) and the institutional quality characteristics. These models show that the individual effect of official supervisory power (OP) on bank stability is negative while it is also significant in some models. A potential reason for this negative association is that a strong supervisor could force banks to allocate credit for private gain and/or political purposes. This weak integrity in the lending process could decrease bank stability due to lower asset quality (Beltratti and Stulz, 2012). Overall, the finding that supervisory power (OP) decreases bank stability conforms to the "private interest view" of bank regulation and supervision (Barth et al, 2008).

Regarding the conditioning effects of institutional quality, we find in model 7 of Table 3 that the interaction term between official supervisory power (OS) and control of corruption (CCOR) is positive and significant. This finding provides some evidence that the negative effect of supervisory power (OP) on stability weakens at higher levels of control of corruption. Control of corruption could limit the room of maneuver that strong supervisors have in order to influence bank credit allocation for private gain. This could strengthen lending integrity, lead to better asset quality and improve bank stability through a higher probability of loan repayment. Thus, the weakening of the negative effect of supervisory power (OP) on stability in the presence of higher control of corruption (CCOR) provides some evidence in support to the H.2 "institutional quality-loan repayment" hypothesis. It is important to note though that this evidence is statistically weak as the interaction term between supervisory power (OP) and control of corruption (CCOR) is significant at the $10 \%$ level.

Moreover, the interaction terms between official supervisory power (OP) and the rest of the institutional quality variables enter models 6-10 of Table 3 with coefficients not significantly different from zero. This suggests that we do not find strong evidence that institutional quality exert a significant conditioning effect on the negative impact of effect of supervisory power on bank stability. The study of Agarwal et al. (2014) provides a potential explanation for this finding. The authors focus on the United States and provide evidence that state bank supervisors, in comparison with their federal counterparts, show more leniency in the supervision process. This leniency contributes to higher bank failure probabilities and lower repayment rates. More importantly, the authors show that the source of such leniency is not the institutional quality of the states' public sector but the comparatively limited access of the state supervisors to regulatory resources such as budgeting, staffing, and training. Similarly, in the context of emerging markets, the negative effect of supervisory power on bank stability could 
relate more to a limited availability of regulatory resources and less to institutional quality characteristics.

\subsubsection{Private Monitoring and Institutional Quality}

The models 1-5 of Table 4 provide the results of the dynamic panel estimations that relate to the conditioning effect of institutional quality on the relationship between private monitoring and bank stability.

Table 4

In these models, we find that the individual effect of private monitoring (PM) on bank stability is positive and statistically significant in some cases (see models 3 and 5 of Table 4). This finding is consistent with previous studies (e.g. Hoque et al., 2015). One channel through which private monitoring regulation could have a beneficial effect on bank stability is the disclosure of accurate information to the public, which would enable private agents to monitor banks more effectively (Hay and Shleifer, 1998). Through another channel, the absence of explicit deposit insurance, which is an important aspect of stringent private monitoring regulation, could motivate depositors to monitor banks intensively and discourage them from engaging in risky activities (Akins et al., 2016).

As far as concerns the conditioning effects of institutional quality, we find in model 3 of Table 4 that the interaction term between private monitoring (PM) and the rule of law (RL) is negative and significant at the $5 \%$ level. The positive individual effect of private monitoring on bank stability subdues at higher levels of rule of law. This finding denotes a substitution relationship between private monitoring regulation and the rule of law concerning their effect on bank stability. Similarly, the interaction term between private monitoring (PM) and creditor rights (CR) enters model 4 of Table 4 with a negative and significant, at the $10 \%$ level, coefficient. In combination, the latter two findings suggest that the positive effect of private monitoring on bank stability weakens in the presence of efficient institutional mechanisms that increase the probability of loan repayment. Thus, an efficient judiciary and legislation that protects lenders, render private monitoring less beneficial to bank stability. This is consistent with the H.2 "institutional quality-loan repayment" hypothesis. This finding also means that private monitoring is more beneficial to bank stability in an environment that the loan repayment institutional mechanisms are weak and uncertain. In such an environment, the higher disclosure and the improvement in the integrity of bank lending and corporate governance that private monitoring induces (Beck et al., 2006; Barth et al., 2008) become of particular importance for bank stability. 
It is noteworthy that the interaction terms between some institutional characteristics that are highly relevant to the capacity of a country's public sector (political stability and control of corruption) do not interact significantly with private monitoring (see models 1 and 2 of Table 4). A potential reason could be that most of the components of the private monitoring index either represent private sector measures (e.g. rating of banks from international rating agencies) or require the absence of public sector involvement (e.g. no deposit insurance scheme). This finding conforms to the view that one of the reasons that regulation that induces private monitoring could be efficient in promoting bank stability is that it can avoid hurdles stemming from shortcomings in the operations of the public sector (Shleifer and Vishny, 1998).

\subsubsection{Activities Restrictions and Institutional Quality}

The models 6-10 of Table 4 depict the results of the dynamic panel estimations relevant to the conditioning effect of institutional quality on the relationship between activities restrictions and bank stability. In these models, the effect of activities restrictions (RES) on bank stability is positive and significant. This finding, consistent with some previous studies (e.g. Agoraki et al., 2011; Hoque et al., 2015), denotes that activities restrictions could prevent banks from engaging in risky non-interest based activities and thus could be conducive to bank stability. The interaction terms in models 6-10 of Table 4 reveal that some institutional quality characteristics enhance significantly the positive effect of activities restrictions on bank stability. This means that institutional quality has a complementary relationship with activities restrictions. In models 6,7 and 8 of Table 4, the interaction terms between activities restriction (RES) and political stability (PS), activities restriction (RES) and control of corruption (CCOR), and activities restriction (RES) and the rule of law (RL) are positive and significant at the $1 \%$ level respectively. The interpretation of these findings has two aspects. The first is that these results are consistent with the H.l "institutional quality-regulation enforcement" hypothesis. A higher level of political stability, control of corruption and rule of law could empower regulators to enforce activities restrictions. The second is that activities restrictions, by inducing banks to focus on the interest-based loan market, render institutional characteristics that increase the probability of loan repayment complements to the positive effect that such regulation exerts on bank stability. This conforms to the "institutional qualityloan repayment" view as reflected in the customised for activities restrictions hypothesis $H .3$. Institutional quality in terms of political stability, control of corruption and the rule of law, could increase the probability of loan repayment by improving the lending terms (Bae and 
Goyal, 2009) and by empowering the mechanisms that enforce loan repayment such as the judicial system (Schiantarelli et al., 2016).

We find less strong evidence that creditor rights and information sharing condition the positive effect of activities restriction on bank stability. The interaction term between activities restrictions (RES) and information sharing (IS) is positive and significant at the 5\% level (see model 10 of Table 4), while the interaction between activities restrictions (RES) and creditor rights (CR) does not carry a significant coefficient (see model 9 of Table 4). A potential reason that creditor rights and information sharing do not interact as significantly with activities restrictions as political stability, control of corruption and the rule of law do, stems from the different attributes of these two types of institutional characteristics. Creditor rights and information sharing are institutional arrangements with the sole purpose of increasing the efficiency of the lending market. Therefore, creditor rights and information sharing do not relate to regulation enforcement and therefore could condition the positive effect of activities restriction on bank stability only through the "institutional quality-loan repayment" (H.3) channel. On the other hand, political stability, control of corruption and the rule of law could complement the positive effect of activities restrictions on bank stability both through the "institutional quality-regulation enforcement" (H.1) and the "institutional quality-loan repayment" (H.3) channel. Nevertheless, it is worth mentioning that the restriction on bank activities is the only type of bank regulation in this study that interacts significantly with the information sharing variable. The findings in model 10 of Table 4 suggest that information sharing enhances the positive effect of activities restrictions on bank stability. Regulation that restricts bank activities forces banks to increase their focus on the traditional loan market. Therefore, banks in the presence of stringent activities restrictions face a wide pool of potential borrowers. In such an environment, information sharing, by providing rich information on these potential borrowers, becomes an essential tool that banks can use in order to reduce adverse selection and borrower moral hazard (Houston et al., 2010; Dierkes et al., 2013).

\subsubsection{The individual effect of institutional quality and the effect of the control variables}

Overall, we find that the individual effect of political stability (PS) on bank stability is positive and in some cases significant. This finding is in line with Ghosh (2016) who shows that the recent political turmoil in the Middle East due to the "Arab spring" had a detrimental effect on bank stability. Similarly, we find that the association of the rule of law (RL) with bank stability is positive and significant. Somewhat surprisingly, most models in Tables 3 and 4 show that the individual effect of control of corruption (CCOR) on bank stability is negative and 
significant. In the context of emerging markets, higher corruption could enable the most productive firms to access loans in better terms (Chen et al., 2013) ${ }^{13}$. Furthermore, Mendoza et al. (2015) provide evidence that corruption, in some cases, allows firms from emerging markets to improve their performance by enabling them to avoid excessive bureaucracy. Therefore, corruption, in the emerging markets context, could have a positive effect on bank stability by "greasing the wheels" of lending and improving the performance of borrowing firms. The individual effect of creditor rights (CR) on stability is negative and significant in most models of Tables 3, and 4. This result in line with the findings of Houston et al. (2010) and suggests that strong creditor rights could decrease bank stability by inducing banks to rely heavily on collateral and relax their lending standards. Finally, we find that information sharing (IS) exerts a positive effect on stability. This finding is consistent with previous studies (e.g. Houston et al., 2010) and underlines the importance of credit registries in reducing information asymmetry issues in the credit market.

Concerning the country-level controls, the effect of GDP growth (GDPG) on bank stability is positive and significant in most models. A growing economy generates higher and more stable returns that could enhance bank stability. The country-level corporate governance measure (CGOV) also exerts a positive and significant effect on bank stability. Banks located in countries where their management teams are highly accountable to investors enjoy higher levels of stability. We also find that bank stability has a positive and significant association with the level of economic development (lnGDPcap) whilst its relationship with inflation (INF) is also significant but negative.

Finally, the effects of the bank-specific controls on stability are broadly consistent in all estimations of Tables 3 and 4 . We find that size (lnTA) exerts a positive and significant effect on bank stability. Larger banks could be more stable due to benefits stemming from economies of scale and scope. The effect of the intermediation ratio (LOAN) on bank stability is also positive and significant in most specifications. Beltratti and Stulz (2012) find that banks with high levels of bank loans have a smaller portfolio of risky securities and thus are more stable. We also find that the loan loss provisions to assets ratio (LLPL) and the equity to assets ratio (EQAS) exert, in most models, a significant effect on stability, which is negative and positive respectively. In addition, most models of Tables 3 and 4 show that bank asset growth (ASTGR)

\footnotetext{
${ }^{13}$ The study of Chen et al., (2013) provides empirical evidence from the loan market of China that although bribery is not sufficient for obtaining a loan, it enables the most productive firms to obtain loans with better terms. Therefore, corruption "greases the wheels" of lending but only for the best performing firms.
} 
has a negative and significant association with stability. These findings are in line with previous empirical research (e.g. Anginer et al., 2014).

\subsection{Further Analysis and Robustness Checks}

\subsubsection{Further Analysis: Z-score Disaggregation}

To enhance the main analysis we follow previous studies (e.g. Houston et al., 2010; Beck et al., 2013) and estimate models that use the three components of the z-score (ROA, the standard deviation of ROA and the bank capital ratio) as separate dependent variables. This exercise enables us to examine if the interaction between institutional quality and bank regulation and supervision exerts an impact on bank stability by affecting the risk and the profitability of bank assets or by merely influencing bank capital.

In this further analysis, we focus on the most significant findings of Tables 3 and 4 (i.e. on the interactions between institutional quality and regulations with a significance level of $1 \%$ or $5 \%$ ). The models that employ as dependent variables the three different components of the $\mathrm{z}$ score are available in Table 5. Note that we use the negative of profit volatility (standard deviation of ROA) such that an increase would denote higher profit stability. Overall, we find that the interactions between institutional quality and bank regulations and supervision affect bank stability more through their effect on profit stability (-lnSDROA) and profitability (ROA) rather than through their effect on bank capital (EQAS).

Table 5

The first three models of Table 5 show that the interaction between capital regulation (CS) and political stability (PS) exerts a positive and significant effect on all the three z-score components while in these models the individual effect of capital regulation (CS) carries a positive coefficient. These findings suggest that higher political stability enhances the positive effect of capital regulation on bank stability both by improving profit stability (-lnSDROA) and profitability (ROA) and by increasing capital ratios (EQAS). These results corroborate the findings of the main analysis and lend further support to the H.1 "institutional qualityregulation enforcement" hypothesis about the interaction between capital regulation and political stability. The models 3-6 of Table 5 repeat this exercise for the interaction between capital regulation (CS) and creditor rights (CR). We find that this interaction exerts a negative and significant effect on profit stability (see model 4 of Table 5). Therefore, the positive individual effect of capital regulation on profit stability weakens in the presence of stronger creditor rights. This finding further corroborates the results of the main analysis that show a 
substitution relationship between capital regulation and creditor rights which is consistent with the H.2 "institutional quality-loan repayment hypothesis".

The models 7-9 of Table 5 show the effect of the interaction term between private monitoring (PM) and the rule of law (RL) on the three z-score components. The coefficient of this interaction carries a negative sign in all these three models but is significant, at the $10 \%$ level, only in model 7 when the dependent variable is profit stability (-lnSDROA). Furthermore, the individual effect of private monitoring (PM) on profit stability is positive and significant at the $5 \%$ level. Thus, the positive effect of private monitoring on bank profit stability subdues at a higher level of rule of law. This result is in line with the findings of the main analysis and lends additional support to the H.2 "institutional quality-loan repayment" hypothesis concerning private monitoring and the rule of law.

The rest of the models of Table 5 (models 10-21) show the effect of the interaction terms between activities restrictions (RES) and institutional quality (political stability, control of corruption, the rule of law, and information sharing) on the components of z-score. These interaction terms are generally positive and significant in the models that the dependent variables are the profit stability (-lnSDROA) indicator (see models 13, 16 and 19 of Table 5) and the profitability (ROA) measure (see models 11, 14 and 17 of Table 5). These findings suggest that the positive effect of activities restrictions on bank profit stability and profitability strengthens in the presence of higher institutional quality. Thus, activities restrictions and institutional quality are complements concerning their effect on the bank profit stability and profitability. These findings are consistent with the results of the main analysis and provide further evidence in support of the H.1 "institutional quality-regulation enforcement" hypothesis and the customized for activities restrictions $H .3$ "institutional quality-loan repayment" hypothesis.

\subsubsection{Robustness Checks: Alternative Measures of Institutional Quality and Principal} Component Analysis

To check the robustness of the empirical findings in the main analysis, we first estimate models that use alternative measures of institutional quality. In this robustness exercise, we focus again on the most significant findings of Tables 3 and 4 (i.e. on the interactions between institutional quality and regulations with a significance level of $1 \%$ or $5 \%$ ).

We source the government integrity index (GI) from the Heritage Foundation as an alternative measure of control of corruption. This index ranges from 0 to 100 with higher values denoting less corruption. Next, we employ the political rights index (PR) from Freedom House as a 
proxy for political stability ${ }^{14}$. This index ranges from 1 to 7 while it is important to note that lower values of this index indicate a higher level of political rights. To proxy for the rule of law, we use the strength of the legal structure (LS) index that we source from the Fraser Index of Economic Freedom. The legal structure index is the average figure of three sub-indices: the integrity of the legal system, the legal enforcement of contracts and the reliability of law enforcement agencies. This index ranges from 0-10 with higher values denoting a stronger legal structure. Finally, as an alternative measure of creditor rights (CR), we use the property rights (PROP) index that we source from the Heritage Foundation. This index measures the extent to which the country's laws protect private property rights and ranges from 0 to 100 .

The results of the dynamic panel estimations that employ these alternative measures of institutional quality are available in models 1-6 of Table $6^{15}$. These are broadly consistent with the findings of the main analysis.

\section{Table 6}

The interaction between capital requirements regulation (CS) and political rights (PR) is negative and significant at the 5\% level while the individual effect of stringent capital regulation (CS) on bank stability is positive (see model 1 of Table 6). Note that higher values of the political rights index (PR) imply weaker political rights. Therefore, the positive effect of capital regulation (CS) on bank stability subdues when political rights are weak. This result further supports the finding of the main analysis that capital regulation and political stability are complements concerning their effect on bank stability in support of the H.1 "institutional quality-regulation enforcement" hypothesis. About private monitoring (PM) we find that its interaction term with legal structure (LS) is negative and significant at the $1 \%$ level (see model 3 of Table 6). The positive effect of private monitoring on bank stability weakens in the presence of institutional mechanisms that increase the probability of loan repayment in line with the "institutional quality-loan repayment" view of hypothesis H.2. Finally, we find that the positive effect of activities restrictions (RES) on bank stability strengthens in the presence of government integrity (GI) and a strong legal structure (LS) while it subdues in the presence

\footnotetext{
14 The political rights index from the Freedom House encompasses political rights and civil liberties. Political rights measure the level of political party competition, actual rule, real power of political parties and the presence of minority groups in politics, while civil liberties measure the degree to which freedom of expression assembly, education and religion is expressed. Although an imperfect alternative measure of political stability, political rights relates closely to political stability (Roe and Siegel, 2011). For example, Acemoglu et al. (2008) provide evidence that political rights decrease social unrest, which could contribute to political stability.

${ }^{15}$ Note that we cannot perform this exercise for information sharing. This is because there is no alternative crosscountry dataset for this variable except the World Bank dataset that we use in the main analysis.
} 
of limited political rights as proxied by the PR variable (see models 5, 6 and 4 of Table 6 respectively).

As a second robustness check, we employ principal component analysis to turn the four bank regulation and supervision variables (CS, OP, PM, RES) into a single bank regulation and supervision variable (REG). Furthermore, using principal component analysis we also turn the institutional quality characteristics into two variables (IQ and CRIS). IQ is the principal component of control of corruption (COR), political stability (POL) and the rule of law (RL), while CRIS is the principal component of creditor rights (CR) and information sharing (IS). The results of the estimations that use the principal component variables are available in models 7 and 8 of Table 6.

In model 7 of Table 6, we find that the interaction term between the bank regulation and supervision variable (REG) and institutional quality (IQ) in terms of the principal component of political stability, control of corruption and the rule of law is positive and significant at the $5 \%$ level. This means that the positive individual effect of bank regulation and supervision on bank stability strengthens at higher levels of institutional quality in terms of political stability, control of corruption and the rule of law. This finding provides further evidence in support of the H.1 "institutional quality-regulation enforcement" hypothesis. On the other hand, the interaction between the bank regulation and supervision variable (REG) and the principal component of creditor rights and information sharing (CRIS) is negative but not significant (see model 8 of Table 6). This provides only some tentative empirical support to the H.2 "institutional quality-loan repayment" hypothesis in terms of creditor rights and information sharing. The latter finding highlights the importance of using disaggregated measures of institutional quality and bank regulations in order to obtain a more meaningful set of empirical results.

\section{Conclusion}

This study examines if institutional quality conditions the impact of bank regulations and supervision on bank stability, as measured by the z-score, in emerging and developing economies over the 2004-2013 period. We provide evidence of the existence of such conditioning effects but these depend on the type of institutional quality and on the type of bank regulation.

The empirical findings show that political stability and control of corruption tend to exhibit a complementary relationship with some bank regulations concerning the effect of the latter on bank stability. We find that political stability enhances the positive effect of capital regulations 
and activities restrictions on bank stability. Moreover, the positive effect of activities restrictions on bank stability also strengthens at higher levels of control of corruption. These results are in line with the "institutional quality-regulation enforcement" hypothesis, which posits that good institutions induce regulatory enforcement. On the contrary, we find that institutional quality characteristics that facilitate loan repayment tend to display a substitution relationship with bank regulations. The positive effect of capital regulation on bank stability weakens in the presence of higher levels of rule of law and strong creditor rights. Furthermore, the positive effect of private monitoring on bank stability also subdues when the rule of law is prevalent. The latter findings are consistent with the "institutional quality-loan repayment" hypothesis. However, we do not find strong evidence that the negative effect of supervisory power on bank stability is conditioned by institutional quality. In further analysis, we decompose the z-score measure and find that institutional quality conditions the effect of bank regulations on stability more though influencing profit volatility and profitability rather than by affecting bank capital.

Overall, taking into account the interactions between bank regulations and institutional quality leads to an improved understanding of the institutional framework in which specific bank regulations could be more effective in promoting bank stability. Hence, this study provides some policy implications that could be useful in the light of the full implementation of Basel III in 2019. Firstly, political stability could be a prerequisite for capital regulation and activities restrictions to reach their full potential in terms of their beneficial effect on bank stability. Thus, political risk, that is still pervasive in many emerging and developing economies, could limit the effectiveness of such bank regulations. Secondly, capital regulation and private monitoring could be particularly useful for bank stability in emerging and developing economies with weak judicial efficiency (i.e. rule of law) and creditor rights. Given that legal systems are persistent to change, the adoption of more stringent capital regulation and regulation that induces private monitoring in such countries could promote bank stability. Finally, the absence of strong evidence that institutional quality conditions the negative effect of supervisory power on bank stability denotes that a potential source of this negative association could be the lack of access to regulatory resources and staff training. 


\section{References}

Acemoglu, D., Johnson, S., Robinson, J. A., and Yared, P. (2008),' Income and democracy', American Economic Review, Vol. 98(3), pp. 808-842.

Acemoglu, D., and Verdier, T. (2000),'The choice between market failures and corruption', The American Economic Review, Vol. 90(1), pp. 194-211.

Acharya, V. V., Amihud, Y., and Litov, L. (2011),'Creditor rights and corporate risk-taking', Journal of Financial Economics, Vol. 10(1), pp. 150-166.

Agarwal, S., Lucca, D., Seru, A., and Trebbi, F. (2014), 'Inconsistent regulators: Evidence from banking', The Quarterly Journal of Economics, Vol. 129(2), pp. 889-938.

Agoraki, M. E. K., Delis, M. D., and Pasiouras, F. (2011),'Regulations, competition and bank risktaking in transition countries', Journal of Financial Stability, Vol. 7, pp. 38-48.

Aidt, T. S. (2003),'Economic analysis of corruption: A survey', The Economic Journal, Vol. 113(491), pp. F632-F652

Akins, B., Dou, Y., and Ng, J. (2017),'Corruption in bank lending: The role of timely loan loss recognition', Journal of Accounting and Economics, Vol. 63, pp. 454-487.

Akins, B., Li, L., Ng, J., and Rusticus, T. O. (2016),'Bank Competition and Financial Stability: Evidence from the Financial Crisis', Journal of Financial and Quantitative Analysis, Vol. 51(1), pp. $1-28$.

Alt, J. E., and Lassen, D. D. (2014),'Enforcement and public corruption: Evidence from the American States', The Journal of Law, Economics, \& Organization, Vol. 30(2), pp. 306-338.

Anginer, D., Demirguc-Kunt, A., and Zhu, M. (2014),'How does deposit insurance affect bank risk? Evidence from the recent crisis', Journal of Banking \& Finance, Vol. 48, pp. 312-321.

Anginer, D., and Demirguc-Kunt, A. (2014),'Has the global banking system become more fragile over time?', Journal of Financial Stability, Vol. 13, pp. 202-213.

Arellano, M., and Bond, S. (1991),' Some tests of specification for panel data: Monte Carlo evidence and an application to employment equations', The review of economic studies, Vol. 58(2), pp. 277297

Arellano, M., and Bover, O. (1995),'Another look at the instrumental variable estimation of errorcomponents models', Journal of Econometrics, Vol. 68, pp. 29-51. 
Ashraf, B. N. (2017),'Political institutions and bank risk-taking behaviour', Journal of Financial Stability, Vol. 29, pp. 13-35.

Bae, K-H., and Goyal, V. K. (2009),'Creditor Rights, Enforcement, and Bank Loans', The Journal of Finance, Vol. 64(2), pp. 823-860.

Baker, S. R., Bloom. N., and Davis, S. J. (2015), 'Measuring Economic Policy Uncertainty', Working Paper No. 21633. National Bureau of Economic Research.

Barakat, A., and Hussainey, K. (2013),'Bank governance, relation, supervision, and risk reporting: Evidence from operational risk disclosures in European banks', International Review of Financial Analysis, Vol. 30, pp. 254-273.

Barth, J. R., Caprio Jr, G., and Levine, R. (2004),'Bank regulation and supervision: what works best?', Journal of Financial Intermediation, Vol. 13, pp. 205-248.

Barth, J. R., Caprio Jr, G., and Levine, R. (2008),'Bank Regulations Are Changing: For Better or Worse', World Bank Policy Research Working Paper, No. 4646.

Barth, J. R., Caprio Jr, G., and Levine, R. (2013),'Bank Regulation and Supervision in 180 Countries From 1999 to 2011', National Bureau of Economic Research Working Paper No. 18733.

Beck, T., Demirguc-Kunt, A., and Levine, R. (2006),'Bank supervision and corruption in lending', Journal of Monetary Economics, Vol. 53, pp. 2131-2163.

Beck, T., Jonghe, O. D., and Schepens, G. (2013),'Bank competition and stability: Cross-country heterogeneity', Journal of Financial Intermediation, Vol. 22, pp. 218-244.

Beltratti, A., and Stulz, R. M. (2012),'The credit crisis around the globe: Why did some banks perform better?', Journal of Financial Economics, Vol. 105, pp. 1-17.

Berger, A. N., and Udell, G. F. (2006),'A more complete conceptual framework for SME finance', Journal of Banking \& Finance, Vol. 30(11), pp. 2945-2966.

Bester, H. (1985),'Screening vs. rationing in credit markets with imperfect information', American Economic Review, Vol. 57, pp. 850-855.

Blundell, R., and Bond, S. (1998),' Initial conditions and moment restrictions in dynamic panel data models', Journal of Econometrics, Vol. 87(1), pp. 115-143.

Bond, S. R. (2002),'Dynamic panel data models: A guide to micro data methods and practice', Portuguese Economic Journal, Vol. 1(2), pp. 141-162.

Bouvard, M., Chaigneau, P., and Motta, A. D. (2015),'Transparency in the Financial System: Rollover risk and crises', The Journal of Finance, Vol. 70(4), pp. 1805-1837.

Bradley, D., Pantzalis, C., and Yuan, X. (2016),'Policy risk, corporate political strategies, and the cost of debt', Journal of Corporate Finance, Vol. 40, pp. 254-275.

Bushman, R. M., Piotroski, J. D., and Smith, A. J. (2004),'What determines corporate transparency?', Journal of Accounting Research, Vol. 42(2), pp. 207-252.

Caballero, R. J., Cowan, K. N., Engel, E. M. R. A., and Micco, A. (2013),'Effective labor regulation and microeconomic flexibility', Journal of Development Economics, Vol. 101, pp. 92-104.

Chen, Y., Liu, M., and Su, J. (2013),' Greasing the wheels of bank lending: Evidence from private firms in China', Journal of Banking \& Finance, Vol.37(7), pp. 2533-2545

Chong, A., La Porta, R., Lopez-De-Silanes, F., and Shleifer, A. (2014),'Letter grading government efficiency', Journal of the European Economic Association, Vol. 12(2), pp. 277-299.

Daher, M. (2017),'Creditor control rights, capital structure, and legal enforcement', Journal of Corporate Finance, Vol. 44, pp. 308-330.

Dagher, J., Dell'Ariccia, G., Laeven, L., Ratnovski, L., and Tong, H. (2016),'Benefits and Costs of Bank Capital', Staff Discussion Note SDN/16/04. International Monetary Fund.

Damania, R., Fredriksson, P. G., and Mani, M. (2004),'The persistence of corruption and regulatory compliance failures: Theory and evidence', Public Choice, Vol. 121(3), pp. 363-390.

Delis, M. D. (2012),'Bank competition, financial reform, and institutions: The importance of being developed', Journal of Development Economics, Vol. 97(2), pp. 450-465.

Delis, M. D., and Staikouras, P. K. (2011),'Supervisory effectiveness and bank risk', Review of Finance, Vol. 15(3), pp. 511-543.

Delis, M. D., Tran, K. C., Tsionas, E. G. (2012),'Quantifying and explaining parameter heterogeneity in the capital regulation-bank risk nexus', Journal of Financial Stability, Vol. 8, pp. 57-68. 
Demirguc-Kunt, A., and Huizinga, H. (2010),'Bank activity and funding strategies: The impact on risk and returns', Journal of Financial Economics, Vol. 98(3), pp. 626-650

DeYoung, R., Torna, G. (2013),'Nontraditional banking activities and bank failures during the financial crisis' Journal of Financial Intermediation, Vol. 22(3), pp. 397-421.

Dierkes, M., Erner, C., Langer, T., and Norden, L. (2013),'Business credit information sharing and default risk of private firms', Journal of Banking \& Finance, Vol. 37(8), pp. 2867-2878.

Drakos, A. A., Kouretas, G. P., and Tsoumas, C. (2016),'Ownership, interest rates and bank risk-taking in Central and Eastern European countries', International Review of Financial Analysis', Vol. 45, pp. 308-319.

Dreher, A., and Gassebner, M. (2013), 'Greasing the wheels? The impact of regulations and corruption on firm entry', Public Choice, Vol. 155(3-4), 413-432.

Fang, Y., Hasan, I., and Marton, K. (2014),'Institutional development and bank stability: Evidence from transition countries', Journal of Banking \& Finance, Vol. 39, pp. 160-176.

Fosu, S. (2014), 'Credit information, consolidation and credit market performance: Bank-level evidence from developing countries', International Review of Financial Analysis, 32, 23-36.

Francis, B. B., Hasan, I., and Zhu, Y. (2014), 'Political uncertainty and bank loan contracting', Journal of Empirical Finance, Vol. 29, pp. 281-286.

Ghosh, S. (2016),'Political transition and bank performance: How important was the Arab Spring?', Journal of Comparative Economics, Vol. 44(2), pp. 372-382.

Haldane, A., and Neumann, T. (2017),' Complexity in regulation', The Palgrave Handbook of European Banking, pp. 323-347.

Hanousek, J., Shamshur, A., and Tresl, J. (2017),'Firm efficiency, foreign ownership and CEO gender in corrupt environments', Journal of Corporate Finance. Available: https://doi.org/10.1016/i.jcorpfin.2017.06.008

Hay, J. R., and Shleifer, A. (1998),'Private enforcement of public laws: A theory of legal reform', The American Economic Review, Vol. 88(2), pp. 398-403.

Hoque, H., Andriosopoulos, D., Andriosopoulos, K., Douady, R. (2015),'Bank regulation, risk and return: Evidence from the credit and sovereign debt crises', Journal of Banking \& Finance, Vol. 50, pp. 455-474.

Houston, J. F., Lin, C., Lin, P., and Ma, Y. (2010),'Creditor rights, information sharing, and bank risk taking', Journal of Financial Economics, Vol. 96, pp. 485-512.

Jappelli, T., Pagano, M., and Bianco, M. (2005),'Courts and banks: Effects of judicial enforcement on credit markets', Journal of Money, Credit and Banking, Vol. 37, pp. 223-244.

Jiang, T., and Nie, H. (2014), 'The stained China miracle: Corruption, regulation, and firm performance', Economics Letters, Vol. 123(3), pp. 366-369.

Klomp, J., and Haan, J. (2014), 'Bank regulation, the quality of institutions, and banking risk in emerging and developing countries: an empirical analysis', Emerging Markets Finance and Trade, Vol 50(6), pp. 19-40.

Klomp, J., and Haan, J. D. (2015),'Bank regulation and financial fragility in developing countries: Does bank structure matter?', Review of Development Finance, Vol. 5(2), pp. 82-90.

Knack, S., and Keefer, P. (1995),'Institutions and economic performance: Cross-country tests using alternative institutional measures', Economics and Politics, Vol. 7(3), pp. 207-227.

Kohler, M. (2015),'Which banks are more risky? The impact of business models on bank stability', Journal of Financial Stability, Vol. 16, pp. 195-212.

Kopecky, K. J., and VanHoose, D. (2006),'Capital regulation, heterogeneous monitoring costs, and aggregate loan quality', Journal of Banking \& Finance, Vol. 30(8), pp. 2235-2255.

Laeven, L., and Levine, R. (2009),'Bank governance, regulation and risk taking', Journal of Financial Economics, Vol. 93(2), pp. 259-275.

Laeven, L., and Majnoni, G. (2005),'Does judicial efficiency lower the cost of credit?', Journal of Banking \& Finance, Vol. 29(7), pp. 1791-1812.

Laeven, L., Ratnovski, L., and Tong, H. (2016),'Bank size, capital, and systemic risk: Some international evidence', Journal of Banking \& Finance, Vol. 69(1), pp. S25-S34. 
Mendoza, R. U., Lin, R. A., and Lopez, A. O. (2015),'Grease or sand in the wheels of commerce? Firm level evidence on corruption and SMES', Journal of International Development, Vol. 27(4), pp. 415-439.

Oliva, P. (2015),'Environment regulations and corruption: Automobile emissions in the Mexico City', Journal of Political Economy, Vol. 123(3), pp.686-724.

Olken, B. A. (2007),'Monitoring corruption: Evidence from a field experiment in Indonesia', Journal of Political Economy, Vol. 115(2), pp. 200-249.

Osei-Assibey, R., and Asenso, J. K. (2015),'Regulatory capital and its effect on credit growth, nonperforming loans and bank efficiency: Evidence from Ghana', Journal of Financial Economic Policy, Vol. 7(4), pp. 401-420.

Padilla, A. J., and Pagano, M. (1997),'Endogenous communication among lenders and entrepreneurial incentives', Review of Financial Studies, Vol. 10(1), pp. 205-236.

Padilla, A. J., and Pagano, M. (2000),'Sharing default information as a borrower discipline device', European Economic Review, Vol. 44(10), pp. 1951-1980.

Pasiouras, F., Tanna, S., and Zopounidis, C. (2009),'The impact of banking regulations on banks' cost and profit efficiency: Cross-country evidence', International Review of Financial Analysis, Vol. 18, pp. 294-302.

Tan, Y., and Floros, C. (2013),'Risk, capital and efficiency in Chinese banking', Journal of International Financial Markets, Institutions and Money, Vol. 26, pp. 378-393.

Roe, M. J., and Siegel, J. I. (2011),'Political instability: Effects on financial development, roots in the severity of economic inequality', Journal of Comparative Economics, Vol. 39(3), pp. 279-309.

Schiantarelli, F., Stacchini, M., and Strahan, P. E. (2016),'Bank quality, judicial efficiency and borrower runs: Loan repayment delays in Italy', Working Paper No. 22034. The National Bureau of Economic Research.

Shehzad, C. T., and Haan, J. D. (2015),'Supervisory powers and bank risk taking', Journal of International Financial Markets, Institutions \& Money, Vol. 39, pp. 15-24.

Shleifer, A., and Vishny, R. W. (1998), 'The Grabbing Hand: Government pathologies and their cures', MA: Harvard University Press.

Windmeijer, F. (2005),'A finite sample correction for the variance of linear efficient two-step GMM estimators', Journal of Econometrics, Vol. 126, pp. 25-51. 


\section{Tables and Figures}

Table 1: Variable definitions and sources

\begin{tabular}{|c|c|c|}
\hline $\begin{array}{l}\text { Variables } \\
\text { Bank Stability }\end{array}$ & Definition & Sources \\
\hline \multicolumn{3}{|l|}{ Bank Stability } \\
\hline $\operatorname{lnZ}$-score & $\begin{array}{l}\text { The natural logarithm of (ROA+EQAS)/SDROA, where EQAS is the capital to } \\
\text { assets ratio, and SDROA is standard deviation of return on assets, and ROA is return } \\
\text { on assets. A higher Z-score indicates a higher level of bank stability, while a lower } \\
\text { value of Z-score indicates a higher level of insolvency risk. }\end{array}$ & BankScope \\
\hline \multicolumn{3}{|l|}{ Bank regulations } \\
\hline $\begin{array}{l}\text { Official } \\
\text { power }\end{array}$ & $\begin{array}{l}\text { Measure the degree to which country's bank supervisory agency has the authority to } \\
\text { take specific actions. It is composed of the answers from specific survey questions: } \\
\text { (1) Does the supervisory agency have the right to meet the external auditors about } \\
\text { banks? (2) Are auditors required to communicate directly to the supervisory agency } \\
\text { about elicit activities, fraud, or insider abuse? (3) Can supervisors take legal action } \\
\text { against external auditors for negligence? (4) Can the supervisory authority force a } \\
\text { bank to change its internal organization structure? (5) Are off-balance sheet items } \\
\text { disclosed to supervisors? (6) Can the supervisory agency order the bank's directors } \\
\text { or management to constitute provision to cover actual or potential losses? (7) Can the } \\
\text { supervisory agency suspend the directors' decision to distribute (a) dividends, (b) } \\
\text { bonuses, and (c) management fees? (8) Can the supervisory agency supersede the } \\
\text { rights of bank shareholders and declare a bank insolvent? (9) Can the supervisory } \\
\text { agency suspend some or all ownership rights? (1) Can the supervisory agency (a) } \\
\text { supersede shareholder rights, (b) remove and replace management, and (c) remove } \\
\text { and replace directors? The official supervisory index has a maximum value of } 14 \text { and } \\
\text { a minimum value of } 0 \text {, where larger numbers indicate greater power. }\end{array}$ & $\begin{array}{l}\text { Bank Regulation } \\
\text { and Supervision } \\
\text { Database, World } \\
\text { Bank; Barth et al. } \\
\text { (2013) }\end{array}$ \\
\hline Capital Regulation & Measure the amount of capital banks must hold and the stringency of regulation on & Bank Regulation \\
\hline
\end{tabular}


the nature and source of regulatory capital. It is composed of the answers from specific survey questions: (1) Is the capital-asset ratio risk weighted in line with the Basel I guidelines? (2) Does the minimum capital-asset ratio vary as a function of an individual bank's credit risk? (3) Does the minimum capital-asset ratio vary as a function of market risk? (4) Before minimum capital adequacy is determined, which of the following are deducted from the book value of capital? Market value of loan losses not realized in accounting book? Unrealized losses in securities portfolios? Or unrealized foreign exchange losses? (5) What fraction of revaluation gains is allowed as part of capital? (6) Are the sources of funds to be used as capital verified by the regulatory/supervisory authorities? (7) Can the initial disbursement or subsequent injections of capita; be done with assets other than cash or government securities? And (8) Can initial disbursement of capital be done with borrowed funds? Larger values of this index of bank capital regulation indicate more stringent capital regulation. The maximum possible value is 10 , while the minimum possible value is 0 .

Activities restrictions

Private monitoring

Institutional Quality
Control of corruption

Measure the degree to which national regulations restrict banks from engaging in (1) securities activities, (2) insurance activities, and (3) real estate activities. More specifically, securities activities refer to securities underwriting, brokering, dealing, and all aspects of the mutual fund industry. Insurance activities involve insurance underwriting and selling. And real estate activities refer to real estate investment, development, and management. The index values for securities, insurance, and real estate range from 1 to 4 , where larger values indicate more restrictions on banks performing each activity. In particular, 4 signifies prohibited, 3 indicates that there are tight restrictions on the provision of the activity, 2 means that the activity is permitted but with some limits, and 1 signals that the activity is permitted. The index ranges from 3 to 12 with higher values denoting more restrictions.

Measure the degree to which regulatory and supervisory policies encourage the private monitoring of banks that builds on an array of individual questions contained in the survey. Specifically, the private monitoring index is composed of information on (1) whether bank directors and officials are legally liable for the accuracy of information disclosed to the public, (2) whether banks must publish consolidated accounts, (3) whether banks must be audited by certified international auditors, (4) whether 100 percent of the largest 10 banks are rated by international rating agencies, (5) whether off-balance sheet items are disclosed to the public, (6) whether banks must disclose their risk management procedures to the public, (7) whether accrued, though unpaid interest/principal, enter the income statement while the loan is still non-performing, (8) whether subordinated debt is allowable as part of capital, and (9) whether there is no explicit deposit insurance system and no insurance was paid the last time a bank failed. Thus, the maximum value of the private monitoring index is 12 and the minimum value is 0 , where larger values indicate greater regulatory empowerment of the monitoring of banks by private investors.

Rule of law

Political stability

Creditor rights

Information sharing

Control variables $\operatorname{lnTA}$

\section{aracteristics}

The extent to which public power is exercised for private gain. Range -2.5 to +2.5 .

The extent to which agents have confidence in and abide by the rules of society. Range -2.5 to +2.5 .

The likelihood that the government will be destabilized or overthrown by unconstitutional or violent means. Range -2.5 to +2.5 .

The degree to which collateral and bankruptcy laws protect the rights of borrowers and lenders and thus facilitate lending. Range 0-10.

Rules and practices affecting the coverage, scope and accessibility of credit information available. Range 0-6.

Natural logarithm of total assets and Supervision Database, World Bank; Barth et al. (2013)

Bank Regulation and Supervision Database, World Bank; Barth et al. (2013)

Bank Regulation and Supervision Database, World Bank; Barth et al. (2013)

World

Governance Indicators

World

Governance

Indicators

World

Governance

Indicators

Doing Business

Doing Business

BankScope 


\begin{tabular}{|c|c|c|}
\hline LLPL & Loan loss provision to total loans & BankScope \\
\hline EQAS & Bank equity to total assets & BankScope \\
\hline LOAN & The ratio of loans to total assets. & BankScope \\
\hline ASTGR & Real growth rate of bank assets (inflation adjusted). & BankScope \\
\hline CGOV & $\begin{array}{l}\text { Corporate board efficacy indicator. Range } 1-7 \text {. Higher values denote that managers } \\
\text { are more accountable to outside shareholders and investors. }\end{array}$ & $\begin{array}{l}\text { World Economic } \\
\text { Forum } \\
\text { BankScope }\end{array}$ \\
\hline HHI & $\begin{array}{l}\text { Herfindahl-Hirschman Index (HHI) based on bank loans. Range } 0-1 \text {. Higher values } \\
\text { denote more concentration of the banking industry of a country. }\end{array}$ & \\
\hline GDPG & Rate of real per capita gross domestic product (GDP) growth & World \\
\hline GDPC & Natural logarithm of gross domestic product (GDP) in US dollars & Development \\
\hline INFL & Consumer price inflation rate & Indicators \\
\hline \multicolumn{3}{|c|}{ Additional variables used in Further Analysis and Robustness checks } \\
\hline S. Deviation of ROA & Three-year rolling-window standard deviation of the return on assets. & BankScope \\
\hline ROA & Return on Average Assets & BankScope \\
\hline Political rights & $\begin{array}{l}\text { The index is calculated by average scores for political rights and civil liberties. } \\
\text { Political rights measure the levels of political party competition, actual rule, real } \\
\text { power of other political parties and the present of minority groups in politics. Civil } \\
\text { liberties measure the degree to which freedom of expression, assembly, education } \\
\text { and religion is expressed and freedom of economic activities and the fairness of legal } \\
\text { system. Values range from } 1 \text { to } 7 \text {, a lower value indicates a higher level of political } \\
\text { rights. }\end{array}$ & Freedom House \\
\hline Government Integrity & $\begin{array}{l}\text { Measures the levels of freedom of corruption in a country. The index is the average } \\
\text { scores of six sub-factors: public trust in politicians, irregular payments and bribes, } \\
\text { transparency of government policymaking, absence of corruption, perceptions of } \\
\text { corruption, and governmental and civil service transparency. Range } 0-100 \text {. }\end{array}$ & $\begin{array}{l}\text { Heritage } \\
\text { Foundation index }\end{array}$ \\
\hline Property rights & $\begin{array}{l}\text { Measure of the extent to which a country's laws protect private property rights. } \\
\text { Range } 0-100 \text {. }\end{array}$ & $\begin{array}{l}\text { Heritage } \\
\text { Foundation index }\end{array}$ \\
\hline Legal structure & $\begin{array}{l}\text { The average figure of three legal structure indices. (1) Integrity of legal system } \\
\text { which measures the strength and impartially of legal system and the observance of } \\
\text { the law. (2) Legal enforcement of contracts measures the time cost and monetary cost } \\
\text { required to collect a clear-cut debt, (3) Reliability of police measures the reliability } \\
\text { of police services to enforce law and order in a country. A higher value implies a } \\
\text { stronger legal structure. Range } 0-10 \text {. }\end{array}$ & $\begin{array}{l}\text { Fraser economic } \\
\text { freedom index }\end{array}$ \\
\hline
\end{tabular}

Table 2: Descriptive statistics

\begin{tabular}{|c|c|c|c|c|c|}
\hline Variable & Obs & Mean & Std. Dev. & Min & Max \\
\hline Natural logarithm of Z-score (Lnz-score) & 5854 & 3.303 & 1.330 & -5.016 & 10.575 \\
\hline Restriction on banking activities (RES) & 5695 & 7.621 & 1.988 & 3 & 12 \\
\hline Capital stringency (CS) & 5695 & 6.805 & 1.765 & 1 & 10 \\
\hline Official supervisory power (OP) & 5695 & 11.148 & 2.457 & 4 & 14 \\
\hline Private monitoring (PM) & 5695 & 7.930 & 1.432 & 4 & 11 \\
\hline
\end{tabular}


Control of corruption (CCOR)

Rule of law (RL)

Creditor rights (CR)

Information sharing (IS)

Board Efficacy (CGOV)

$\mathrm{HHI}$ index (HHI)

Bank size (lnTA)

Asset growth \% (ASTGR)

Equity to assets \% (EQAS)

Loans to assets \% (LOAN)

Provisions to loans \% (LLPL)

GDP growth \% (GDPG)

Ln GDP per capita (GDPC)

Inflation \% (INF)
5690

5690

5611

5611

5262

5623

5695

5695

5695

5585

5554

5813

5813

5813
$-0.542$

$-0.538$

5.124

2.996

4.427

0.171

13.082

7.726

14.643

62.873

1.910

4.739

7.959

9.968
0.501

0.522

2.233

2.507

0.386

0.123

2.185

5.789

8.982

5.193

2.934

3.454

1.070

8.781
$-1.91$

$-2.11$

0

0

3.365

0.031

2.303

$-3.566$

3.567

23.820

0.026

$-14.149$

4.664

$-11.161$
1.48

1.6

10

6

6.021

1

21.947

17.504

91.725

96.312

48.167

20.487

12.174

75.438

Table 3. The Conditioning Effects of Institutional Quality on the Relationship between Bank Regulations and Bank Stability: The Cases of Capital Regulation and Supervisory Power 


\begin{tabular}{|c|c|c|c|c|c|c|c|c|c|c|}
\hline VARIABLES & $\begin{array}{c}\text { (1) } \\
\text { Lnz-score }\end{array}$ & $\begin{array}{c}(2) \\
\text { Lnz-score }\end{array}$ & $\begin{array}{c}\text { (3) } \\
\text { Lnz-score }\end{array}$ & $\begin{array}{c}4) \\
\text { Lnz-score }\end{array}$ & $\begin{array}{c}(5) \\
\text { Lnz-score }\end{array}$ & $\begin{array}{c}(6) \\
\text { Lnz-score }\end{array}$ & $\begin{array}{c}\text { (7) } \\
\text { Lnz-score }\end{array}$ & $\begin{array}{c}(8) \\
\text { Lnz-score }\end{array}$ & $\begin{array}{c}(9) \\
\text { Lnz-score }\end{array}$ & $\begin{array}{c}(10) \\
\text { Lnz-score }\end{array}$ \\
\hline L.Lnz-score & $\begin{array}{c}0.477 * * * \\
(0.0308)\end{array}$ & $\begin{array}{c}0.469 * * * \\
(0.0309)\end{array}$ & $\begin{array}{c}0.466 * * * \\
(0.0308)\end{array}$ & $\begin{array}{c}0.459 * * * \\
(0.0303)\end{array}$ & $\begin{array}{c}0.466^{* * * *} \\
(0.0318)\end{array}$ & $\begin{array}{c}0.478 * * * \\
(0.0303)\end{array}$ & $\begin{array}{c}0.470 \text { *** } \\
(0.0302)\end{array}$ & $\begin{array}{c}0.463 * * * \\
(0.0307)\end{array}$ & $\begin{array}{c}0.479 * * * \\
(0.0316)\end{array}$ & $\begin{array}{c}0.464 * * * \\
(0.0306)\end{array}$ \\
\hline $\operatorname{lnTA}$ & $\begin{array}{c}0.117 \text { **** } \\
(0.0286)\end{array}$ & $\begin{array}{c}0.0926 * * * \\
(0.0296)\end{array}$ & $\begin{array}{c}0.0836 * * * \\
(0.0303)\end{array}$ & $\begin{array}{c}0.0888 * * * \\
(0.0280)\end{array}$ & $\begin{array}{c}0.0933 * * * \\
(0.0276)\end{array}$ & $\begin{array}{c}0.105 * * * * \\
(0.0273)\end{array}$ & $\begin{array}{c}0.116 \text { **** } \\
(0.0285)\end{array}$ & $\begin{array}{c}0.109 * * * \\
(0.0278)\end{array}$ & $\begin{array}{c}0.0890 * * * \\
(0.0295)\end{array}$ & $\begin{array}{c}0.0898 * * * \\
(0.0299)\end{array}$ \\
\hline ASTGR & $\begin{array}{c}-0.231 * * * \\
(0.0648)\end{array}$ & $\begin{array}{c}-0.227 \text { *** } \\
(0.0647)\end{array}$ & $\begin{array}{c}-0.226 * * * \\
(0.0647)\end{array}$ & $\begin{array}{c}-0.218 * * * \\
(0.0640)\end{array}$ & $\begin{array}{c}-0.226 * * * \\
(0.0643)\end{array}$ & $\begin{array}{c}-0.219^{* * *} * \\
(0.0651)\end{array}$ & $\begin{array}{c}-0.224 * * * \\
(0.0647)\end{array}$ & $\begin{array}{c}-0.232 * * * \\
(0.0651)\end{array}$ & $\begin{array}{c}-0.224 * * * \\
(0.0645)\end{array}$ & $\begin{array}{c}-0.219 * * * \\
(0.0645)\end{array}$ \\
\hline EQAS & $\begin{array}{c}0.0089 * * * \\
(0.00230)\end{array}$ & $\begin{array}{c}0.0081 * * * \\
(0.00240)\end{array}$ & $\begin{array}{c}0.0079 * * * \\
(0.00238)\end{array}$ & $\begin{array}{c}0.0089 * * * \\
(0.00235)\end{array}$ & $\begin{array}{c}0.0090 * * * \\
(0.00233)\end{array}$ & $\begin{array}{c}0.0084 * * * \\
(0.00235)\end{array}$ & $\begin{array}{l}0.0092 * * * \\
(0.00231)\end{array}$ & $\begin{array}{c}0.0081 * * * \\
(0.00227)\end{array}$ & $\begin{array}{c}0.0078^{* * *} * \\
(0.00238)\end{array}$ & $\begin{array}{c}0.00883 * * * \\
(0.00237)\end{array}$ \\
\hline LOAN & $\begin{array}{c}0.0050 * * * \\
(0.00177)\end{array}$ & $\begin{array}{c}0.0057 * * * \\
(0.00183)\end{array}$ & $\begin{array}{c}0.0061 * * * \\
(0.00172)\end{array}$ & $\begin{array}{c}0.0063 * * * \\
(0.00176)\end{array}$ & $\begin{array}{c}0.0063 * * * \\
(0.00180)\end{array}$ & $\begin{array}{c}0.00543^{* * * *} \\
(0.00167)\end{array}$ & $\begin{array}{c}0.0052 * * * \\
(0.00170)\end{array}$ & $\begin{array}{c}0.0053 * * * \\
(0.00172)\end{array}$ & $\begin{array}{c}0.0058 * * * \\
(0.00176)\end{array}$ & $\begin{array}{c}0.00637 * * * \\
(0.00175)\end{array}$ \\
\hline LLPL & $\begin{array}{c}-0.0662 * * * \\
(0.0121)\end{array}$ & $\begin{array}{c}-0.0716 * * * \\
(0.0101)\end{array}$ & $\begin{array}{c}-0.0676 * * * \\
(0.0107)\end{array}$ & $\begin{array}{c}-0.0693 * * * \\
(0.0117)\end{array}$ & $\begin{array}{c}-0.0654 * * * \\
(0.0125)\end{array}$ & $\begin{array}{c}-0.0722 * * * \\
(0.0101)\end{array}$ & $\begin{array}{c}-0.0739 * * * \\
(0.0103)\end{array}$ & $\begin{array}{c}-0.0722 * * * \\
(0.00982)\end{array}$ & $\begin{array}{r}-0.0656 * * * \\
(0.0117)\end{array}$ & $\begin{array}{c}-0.0670 * * * * \\
(0.0121)\end{array}$ \\
\hline HHI & $\begin{array}{l}-0.226 \\
(0.183)\end{array}$ & $\begin{array}{c}-0.0744 \\
(0.176)\end{array}$ & $\begin{array}{c}-0.0755 \\
(0.177)\end{array}$ & $\begin{array}{c}-0.0309 \\
(0.175)\end{array}$ & $\begin{array}{c}-0.0430 \\
(0.173)\end{array}$ & $\begin{array}{c}-0.0743 \\
(0.175)\end{array}$ & $\begin{array}{l}-0.106 \\
(0.168)\end{array}$ & $\begin{array}{c}-0.0559 \\
(0.178)\end{array}$ & $\begin{array}{c}0.00791 \\
(0.172)\end{array}$ & $\begin{array}{r}-0.0442 \\
(0.173)\end{array}$ \\
\hline CGOV & $\begin{array}{c}0.0553 * * * \\
(0.0147)\end{array}$ & $\begin{array}{c}0.0547 * * * \\
(0.0155)\end{array}$ & $\begin{array}{c}0.0581 * * * \\
(0.0152)\end{array}$ & $\begin{array}{c}0.0551 * * * \\
(0.0149)\end{array}$ & $\begin{array}{c}0.0562 * * * \\
(0.0157)\end{array}$ & $\begin{array}{c}0.0476 \text { *** } \\
(0.0144)\end{array}$ & $\begin{array}{c}0.0554 * * * \\
(0.0154)\end{array}$ & $\begin{array}{c}0.0600 * * * \\
(0.0150)\end{array}$ & $\begin{array}{c}0.0639 * * * \\
(0.0154)\end{array}$ & $\begin{array}{c}0.0585^{* * *} * \\
(0.0157)\end{array}$ \\
\hline GDPG & $\begin{array}{l}0.00873^{*} \\
(0.00485)\end{array}$ & $\begin{array}{l}0.0104 * * \\
(0.00487)\end{array}$ & $\begin{array}{l}0.0106 * * \\
(0.00492)\end{array}$ & $\begin{array}{l}0.0124 * * \\
(0.00483)\end{array}$ & $\begin{array}{l}0.0105^{* *} \\
(0.00493)\end{array}$ & $\begin{array}{l}0.0107 * * \\
(0.00482)\end{array}$ & $\begin{array}{l}0.0111 * * \\
(0.00476)\end{array}$ & $\begin{array}{l}0.0112 * * \\
(0.00483)\end{array}$ & $\begin{array}{l}0.0104 * * \\
(0.00472)\end{array}$ & $\begin{array}{l}0.0111 * * \\
(0.00482)\end{array}$ \\
\hline GDPC & $\begin{array}{c}0.124 * * * \\
(0.0418)\end{array}$ & $\begin{array}{c}0.140 * * * \\
(0.0407)\end{array}$ & $\begin{array}{c}0.143 * * * \\
(0.0432)\end{array}$ & $\begin{array}{c}0.113 * * * \\
(0.0428)\end{array}$ & $\begin{array}{c}0.143 * * * \\
(0.0412)\end{array}$ & $\begin{array}{c}0.137 * * * \\
(0.0420)\end{array}$ & $\begin{array}{c}0.132 * * * \\
(0.0389)\end{array}$ & $\begin{array}{c}0.135^{* * * *} \\
(0.0418)\end{array}$ & $\begin{array}{c}0.121 * * * \\
(0.0395)\end{array}$ & $\begin{array}{c}0.139 * * * \\
(0.0414)\end{array}$ \\
\hline INF & $\begin{array}{c}-0.0218^{* * *} * \\
(0.00292)\end{array}$ & $\begin{array}{c}-0.0225 * * * \\
(0.00284)\end{array}$ & $\begin{array}{c}-0.0220^{* * * *} \\
(0.00298)\end{array}$ & $\begin{array}{c}-0.0211 * * * \\
(0.00295)\end{array}$ & $\begin{array}{c}-0.0214 * * * \\
(0.00300)\end{array}$ & $\begin{array}{c}-0.0222^{* * * *} \\
(0.00305)\end{array}$ & $\begin{array}{c}-0.0215^{* * * *} \\
(0.00287)\end{array}$ & $\begin{array}{c}-0.0221 * * * \\
(0.00286)\end{array}$ & $\begin{array}{l}-0.0220^{* * * * *} \\
(0.00281)\end{array}$ & $\begin{array}{c}-0.0211^{* * * *} \\
(0.00285)\end{array}$ \\
\hline POL & $\begin{array}{c}1.228 * * * \\
(0.338)\end{array}$ & $\begin{array}{c}0.0161 \\
(0.0552)\end{array}$ & $\begin{array}{c}0.0260 \\
(0.0551)\end{array}$ & $\begin{array}{c}0.0239 \\
(0.0562)\end{array}$ & $\begin{array}{c}0.0426 \\
(0.0538)\end{array}$ & $\begin{array}{c}0.173 \\
(0.477)\end{array}$ & $\begin{array}{c}0.0178 \\
(0.0536)\end{array}$ & $\begin{array}{c}0.0179 \\
(0.0532)\end{array}$ & $\begin{array}{c}0.0240 \\
(0.0544)\end{array}$ & $\begin{array}{c}0.0422 \\
(0.0568)\end{array}$ \\
\hline CCOR & $\begin{array}{c}-0.430 * * * \\
(0.102)\end{array}$ & $\begin{array}{c}-1.181 * * \\
(0.593)\end{array}$ & $\begin{array}{c}-0.482 * * * \\
(0.107)\end{array}$ & $\begin{array}{c}-0.493 * * * \\
(0.105)\end{array}$ & $\begin{array}{c}-0.460 * * * \\
(0.103)\end{array}$ & $\begin{array}{c}-0.467 * * * \\
(0.102)\end{array}$ & $\begin{array}{c}-1.838 * * \\
(0.860)\end{array}$ & $\begin{array}{c}-0.460 * * * \\
(0.106)\end{array}$ & $\begin{array}{c}-0.409 * * * \\
(0.105)\end{array}$ & $\begin{array}{c}-0.490^{* * * *} \\
(0.105)\end{array}$ \\
\hline RL & $\begin{array}{c}0.297 * * \\
(0.116)\end{array}$ & $\begin{array}{c}0.311^{* * *} * \\
(0.113)\end{array}$ & $\begin{array}{c}0.00777 \\
(0.485)\end{array}$ & $\begin{array}{c}0.372 * * * \\
(0.123)\end{array}$ & $\begin{array}{c}0.349 * * * \\
(0.118)\end{array}$ & $\begin{array}{c}0.333 * * * \\
(0.121)\end{array}$ & $\begin{array}{c}0.244 * * \\
(0.117)\end{array}$ & $\begin{array}{l}-0.589 \\
(0.671)\end{array}$ & $\begin{array}{c}0.283^{* *} \\
(0.125)\end{array}$ & $\begin{array}{c}0.381 * * * \\
(0.121)\end{array}$ \\
\hline CR & $\begin{array}{c}-0.0359 * * \\
(0.0141)\end{array}$ & $\begin{array}{c}-0.0317 * * \\
(0.0124)\end{array}$ & $\begin{array}{c}-0.0346^{* *} \\
(0.0139)\end{array}$ & $\begin{array}{l}0.230 * * \\
(0.0935)\end{array}$ & $\begin{array}{c}-0.0304 * * \\
(0.0138)\end{array}$ & $\begin{array}{c}-0.0316^{* *} \\
(0.0136)\end{array}$ & $\begin{array}{l}-0.0190 \\
(0.0126)\end{array}$ & $\begin{array}{l}-0.0249 * \\
(0.0140)\end{array}$ & $\begin{array}{l}-0.215 \\
(0.145)\end{array}$ & $\begin{array}{c}-0.0300 * * \\
(0.0149)\end{array}$ \\
\hline IS & $\begin{array}{c}0.0463 * * * \\
(0.0138)\end{array}$ & $\begin{array}{c}0.0395 * * * \\
(0.0142)\end{array}$ & $\begin{array}{c}0.0393 * * * \\
(0.0140)\end{array}$ & $\begin{array}{l}0.0344 * * \\
(0.0140)\end{array}$ & $\begin{array}{c}0.108 \\
(0.0868)\end{array}$ & $\begin{array}{c}0.0429 * * * \\
(0.0136)\end{array}$ & $\begin{array}{c}0.0482 \text { *** } \\
(0.0138)\end{array}$ & $\begin{array}{c}0.0430 * * * \\
(0.0139)\end{array}$ & $\begin{array}{l}0.0285^{* *} * \\
(0.0133)\end{array}$ & $\begin{array}{c}0.172 \\
(0.108)\end{array}$ \\
\hline RES & $\begin{array}{c}0.527 * * * * \\
(0.0820)\end{array}$ & $\begin{array}{c}0.433 * * * * \\
(0.0853)\end{array}$ & $\begin{array}{c}0.467 * * * \\
(0.0831)\end{array}$ & $\begin{array}{c}0.390 * * * \\
(0.0846)\end{array}$ & $\begin{array}{c}0.484 * * * \\
(0.0831)\end{array}$ & $\begin{array}{c}0.444 * * * \\
(0.0762)\end{array}$ & $\begin{array}{c}0.421 \text { *** } \\
(0.0807)\end{array}$ & $\begin{array}{c}0.459 * * * \\
(0.0810)\end{array}$ & $\begin{array}{c}0.469 * * * \\
(0.0861)\end{array}$ & $\begin{array}{c}0.486 * * * \\
(0.0817)\end{array}$ \\
\hline CS & $\begin{array}{c}0.386 * * * \\
(0.120)\end{array}$ & $\begin{array}{c}0.411^{* *} \\
(0.162)\end{array}$ & $\begin{array}{c}0.340 * * \\
(0.154)\end{array}$ & $\begin{array}{c}0.945 * * * \\
(0.254)\end{array}$ & $\begin{array}{l}0.0880 \\
(0.219)\end{array}$ & $\begin{array}{l}0.194 * \\
(0.103)\end{array}$ & $\begin{array}{l}0.212^{* *} \\
(0.0983)\end{array}$ & $\begin{array}{c}0.176^{*} \\
(0.0969)\end{array}$ & $\begin{array}{c}0.297 * * * \\
(0.103)\end{array}$ & $\begin{array}{c}0.247 * * \\
(0.104)\end{array}$ \\
\hline OP & $\begin{array}{c}-0.520 * * * \\
(0.122)\end{array}$ & $\begin{array}{c}-0.413 * * * \\
(0.125)\end{array}$ & $\begin{array}{c}-0.417 * * * \\
(0.121)\end{array}$ & $\begin{array}{c}-0.455 * * * * \\
(0.115)\end{array}$ & $\begin{array}{c}-0.473 * * * * \\
(0.120)\end{array}$ & $\begin{array}{c}-0.427 * * * \\
(0.147)\end{array}$ & $\begin{array}{l}-0.137 \\
(0.210)\end{array}$ & $\begin{array}{l}-0.257 \\
(0.186)\end{array}$ & $\begin{array}{c}-0.887 \text { **** } \\
(0.338)\end{array}$ & $\begin{array}{c}-0.692 * * * \\
(0.227)\end{array}$ \\
\hline PM & $\begin{array}{l}0.0953 \\
(0.167)\end{array}$ & $\begin{array}{c}0.158 \\
(0.165)\end{array}$ & $\begin{array}{c}0.211 \\
(0.169)\end{array}$ & $\begin{array}{c}0.141 \\
(0.173)\end{array}$ & $\begin{array}{c}0.169 \\
(0.174)\end{array}$ & $\begin{array}{c}0.135 \\
(0.169)\end{array}$ & $\begin{array}{c}0.105 \\
(0.164)\end{array}$ & $\begin{array}{c}0.127 \\
(0.165)\end{array}$ & $\begin{array}{c}0.253 \\
(0.163)\end{array}$ & $\begin{array}{c}0.187 \\
(0.172)\end{array}$ \\
\hline CS*POL & $\begin{array}{c}0.610 * * * \\
(0.169)\end{array}$ & & & & & & & & & \\
\hline $\mathrm{CS} * \mathrm{COR}$ & & $\begin{array}{c}0.355 \\
(0.292)\end{array}$ & & & & & & & & \\
\hline $\mathrm{CS} * \mathrm{RL}$ & & & $\begin{array}{c}0.175 \\
(0.235)\end{array}$ & & & & & & & \\
\hline $\mathrm{CS} * \mathrm{CR}$ & & & & $\begin{array}{c}-0.135 * * * \\
(0.0474)\end{array}$ & & & & & & \\
\hline CS*IS & & & & & $\begin{array}{c}0.0355 \\
(0.0433)\end{array}$ & & & & & \\
\hline OP*POL & & & & & & $\begin{array}{l}-0.0735 \\
(0.201)\end{array}$ & & & & \\
\hline $\mathrm{OP} * \mathrm{COR}$ & & & & & & & $\begin{array}{l}0.554^{*} \\
(0.331)\end{array}$ & & & \\
\hline $\mathrm{OP} * \mathrm{RL}$ & & & & & & & & $\begin{array}{c}0.359 \\
(0.268)\end{array}$ & & \\
\hline $\mathrm{OP}^{*} \mathrm{CR}$ & & & & & & & & & $\begin{array}{c}0.0754 \\
(0.0591)\end{array}$ & \\
\hline OP*IS & & & & & & & & & & $\begin{array}{r}0.0557 \\
(0.0445)\end{array}$ \\
\hline Constant & $\begin{array}{c}-1.312 * * \\
(0.644)\end{array}$ & $\begin{array}{c}-1.210^{*} \\
(0.683)\end{array}$ & $\begin{array}{l}-0.921 \\
(0.698)\end{array}$ & $\begin{array}{c}-1.838 * * \\
(0.738)\end{array}$ & $\begin{array}{l}-0.593 \\
(0.743)\end{array}$ & $\begin{array}{l}-0.928 \\
(0.703)\end{array}$ & $\begin{array}{c}-1.893 * * \\
(0.775)\end{array}$ & $\begin{array}{l}-1.456^{*} \\
(0.767)\end{array}$ & $\begin{array}{c}0.382 \\
(0.987)\end{array}$ & $\begin{array}{c}-0.278 \\
(0.790)\end{array}$ \\
\hline Wald test & $70.0 * * *$ & 75.94 *** & $79.67 * * *$ & $77.16^{* * *}$ & $72.91 * * *$ & $76.13 * * *$ & 71.42 *** & $76.46 * * *$ & $74.63 * * *$ & $6.74 * * *$ \\
\hline $\operatorname{AR}(2) p$-value & 0.500 & 0.529 & 0.495 & 0.487 & 0.530 & 0.532 & 0.546 & 0.488 & 0.483 & 0.522 \\
\hline Hansen $\mathrm{J}$-value & 0.913 & 0.894 & 0.923 & 0.952 & 0.918 & 0.898 & 0.923 & 0.933 & 0.704 & 0.893 \\
\hline Time EF & Yes & Yes & Yes & Yes & Yes & Yes & Yes & Yes & Yes & Yes \\
\hline Country EF & Yes & Yes & Yes & Yes & Yes & Yes & Yes & Yes & Yes & Yes \\
\hline Obs. & 4,689 & 4,689 & 4,689 & 4,689 & 4,689 & 4,689 & 4,689 & 4,689 & 4,689 & 4,689 \\
\hline Instruments & 736 & 736 & 736 & 731 & 734 & 736 & 736 & 736 & 736 & 734 \\
\hline N. of banks & 1,052 & 1,052 & 1,052 & 1,052 & 1,052 & 1,052 & 1,052 & 1,052 & 1,052 & 1,052 \\
\hline
\end{tabular}

Notes: The table reports the effects of the interaction between institutional quality characteristics and capital regulation (CS) and supervisory power (OP) on bank stability over the period between 2004 and 2013. In models (1)-(10), the dependent variable is the natural log of the Z-score (Lnz-score). lnTA is the natural logarithm of bank total assets, ASTGR is the growth rate of a bank's assets, EQAS is bank capitalization, LOAN is loans to total assets, LLPL is the loan loss provisions, HHI is the Herfinfahl-Hirschman Index for bank industry concentration based on loans, CGOV is the corporate governance quality indicator, GDPG is GDP growth rate, GDPC is the natural logarithm of GDP per capita, INF is inflation rate, POL is political stability, CCOR is control of corruption, RL is rule of law, CR is creditor rights, IS is information sharing, CS is capital 
regulation, OP is official supervisory power, RES is bank activities restrictions, PM is private monitoring. ***, ** and * indicate $1 \%, 5 \%$ and $10 \%$ significance levels respectively. Robust standard errors are in parentheses.

Table 4. The Conditioning Effects of Institutional Quality on the Relationship between Bank Regulations and Bank Stability: The Cases of Private Monitoring and Activities Restrictions 


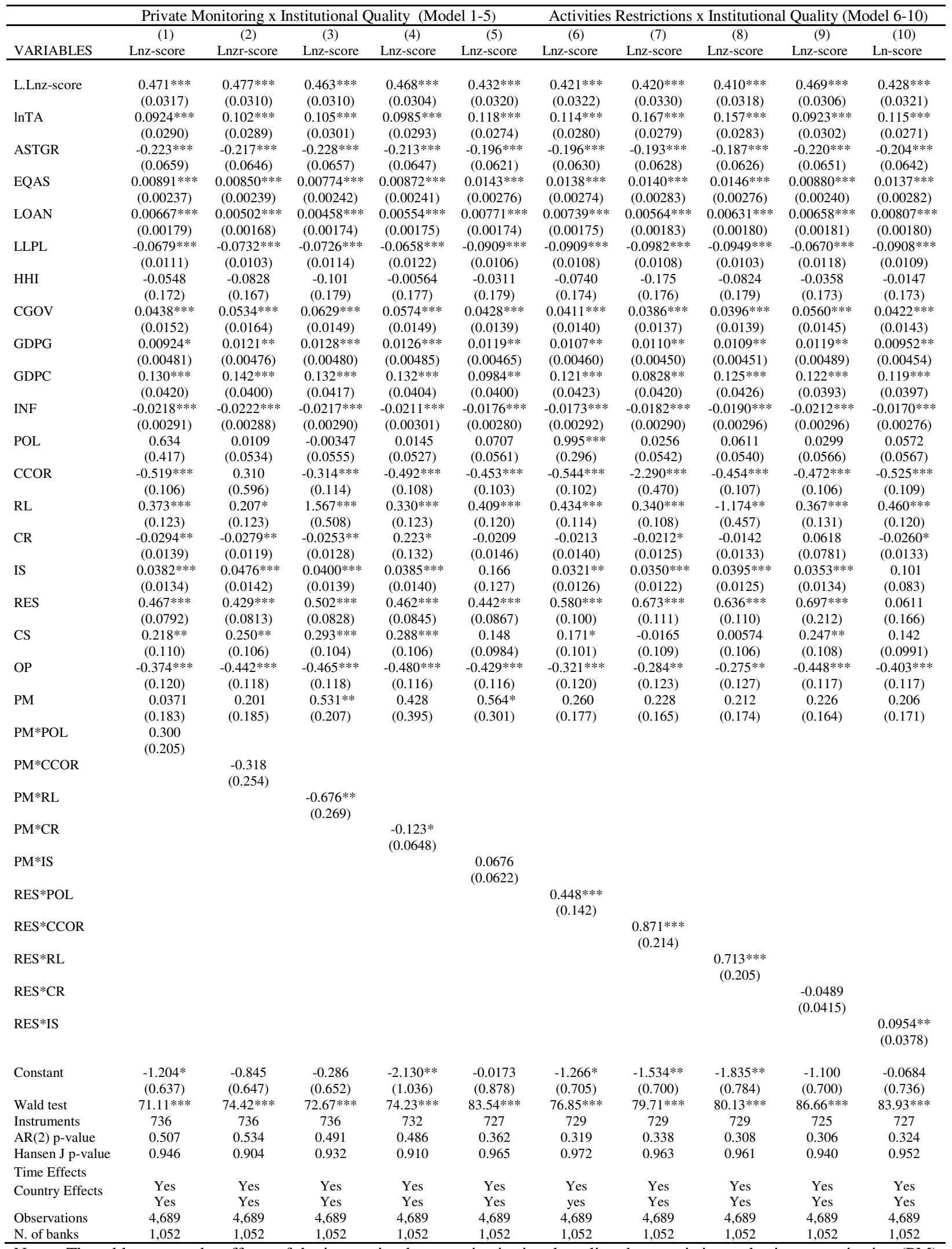

Notes: The table reports the effects of the interaction between institutional quality characteristics and private monitoring (PM) and activities restrictions (RES) on bank stability over the period between 2004 and 2013. In models (1)-(10), the dependent variables is the natural log of the Z-score (Lnz-score). lnTA is the natural logarithm of bank total assets, ASTGR is the growth rate of a bank's assets, EQAS is bank capitalization, LOAN is loans to total assets, LLPL is the loan loss provisions, HHI is the Herfinfahl-Hirschman Index for bank industry concentration based on loans, CGOV is the corporate governance quality indicator, GDPG is GDP growth rate, GDPC is the natural logarithm of GDP per capita, INF is inflation rate, POL is political stability, CCOR is control of corruption, RL is rule of law, CR is creditor rights, IS is information sharing, CS is capital 
regulation, OP is official supervisory power, RES is bank activities restrictions, PM is private monitoring. ***, ** and * indicate $1 \%, 5 \%$ and $10 \%$ significance levels respectively. Robust standard errors are in parentheses. 
Table 5. The Conditioning Effects of Institutional Quality on the Relationship between Bank Regulations and Bank Stability: Results from z-score Disaggregation

\begin{tabular}{|c|c|c|c|c|c|c|c|c|c|c|c|c|c|c|c|c|c|c|c|c|c|}
\hline & Capital & $\mathrm{g} \mathrm{x} \mathrm{Pol}$. Sta &.$(1-3)$ & Capital R & $\mathrm{x}$ Creditor & ights (4-6) & Priv. Mo & it. x Rule o & Law (7-9) & & est. x Pol. St & b. $(10-12)$ & Act. R & t. $x$ Cont. of & or. (13-15) & Act. $R_{s}$ & $x$ Rule of 1 & $\mathrm{w}(16-18)$ & Act. Rest. & $\mathrm{X}$ Xnformation & Sh. $(19-21)$ \\
\hline VARIABLES & $\begin{array}{c}(1) \\
-\operatorname{lnSDROA}\end{array}$ & $\begin{array}{c}(2) \\
\text { ROA }\end{array}$ & $\begin{array}{c}\text { (3) } \\
\text { EQAS }\end{array}$ & $\begin{array}{c}\text { (4) } \\
\text {-InSDROA }\end{array}$ & $\begin{array}{c}(5) \\
\text { ROA }\end{array}$ & $\begin{array}{l}(6) \\
\text { EQAS }\end{array}$ & $\begin{array}{c}(7) \\
-\operatorname{InSDROA}\end{array}$ & $\begin{array}{l}(8) \\
\text { ROA }\end{array}$ & $\begin{array}{c}\text { (9) } \\
\text { EOAS }\end{array}$ & $\begin{array}{l}(10) \\
-\operatorname{lnSDROA}\end{array}$ & $\begin{array}{l}(11) \\
\text { ROA }\end{array}$ & $\begin{array}{l}\text { (12) } \\
\text { EOAS }\end{array}$ & $\begin{array}{c}(13) \\
-\operatorname{InSDROA}\end{array}$ & $\begin{array}{l}(14) \\
\text { ROA }\end{array}$ & $\begin{array}{l}(15) \\
\text { EOAS }\end{array}$ & $\begin{array}{c}(16) \\
-\operatorname{InSDROA}\end{array}$ & $\begin{array}{l}\text { (17) } \\
\text { ROA }\end{array}$ & $\begin{array}{l}\text { (18) } \\
\text { EOAS }\end{array}$ & 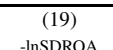 & $\begin{array}{l}(20) \\
\text { ROA }\end{array}$ & $\begin{array}{l}(21) \\
\text { EOAS }\end{array}$ \\
\hline L.-InSDROA & $\begin{array}{l}0.503^{* * * * *} \\
(0.0227)\end{array}$ & & & $\begin{array}{l}0.506 * * * * \\
(0.0223)\end{array}$ & & & $\begin{array}{l}0.483 * * * \\
(0.0229)\end{array}$ & & & $\begin{array}{c}0.490^{* * * *} \\
(0.0228)\end{array}$ & & & $\begin{array}{l}0.501 * * * \\
(0.0219)\end{array}$ & & & $\begin{array}{l}0.495 * * * * \\
(0.0226)\end{array}$ & & & $\begin{array}{l}0.502 * * * * \\
(0.0228)\end{array}$ & & \\
\hline L.ROAA & & $\begin{array}{c}0.427 * * * \\
(0.0765)\end{array}$ & & & $\begin{array}{c}0.448 * * * * \\
(0.0801)\end{array}$ & & & $\begin{array}{c}0.339 * * * \\
(0.0674)\end{array}$ & & & $\begin{array}{l}0.334 * * * \\
(0.0675)\end{array}$ & & & $\begin{array}{l}0.340^{* * * * *} \\
(0.0674)\end{array}$ & & & $\begin{array}{l}0.339 * * * * \\
(0.0679)\end{array}$ & & & $\begin{array}{c}0.335^{* * * *} \\
(0.0675)\end{array}$ & \\
\hline L.EQAS & & & $\begin{array}{l}0.810 * * * \\
(0.0449)\end{array}$ & & & $\begin{array}{c}0.808 * * * * \\
(0.0443)\end{array}$ & & & $\begin{array}{l}0.719 * * * * \\
(0.0478)\end{array}$ & & & $\begin{array}{l}0.714 * * * * \\
(0.0478)\end{array}$ & & & $\begin{array}{l}0.718 * * * \\
(0.0473)\end{array}$ & & & $\begin{array}{l}0.716 * * * * \\
(0.0528)\end{array}$ & & & $\begin{array}{l}0.715 * * * \\
(0.0483)\end{array}$ \\
\hline CS & $\begin{array}{c}0.418^{* * * * *} \\
(0.102)\end{array}$ & $\begin{array}{l}0.0960 \\
(044)\end{array}$ & $\begin{array}{r}0.595 \\
0.644)\end{array}$ & $0.816^{* * * *}$ & $\begin{array}{r}-0.389 \\
0.077\end{array}$ & $\begin{array}{l}-1.101 \\
-1351\end{array}$ & $0.248^{* * * * *}$ & $\begin{array}{r}-0.488 \\
0.3844\end{array}$ & 0.207 & $0.197 * *$ & $\begin{array}{l}-0.314 \\
0.0359\end{array}$ & -0.0413 & $\begin{array}{l}0.142 \\
0.027\end{array}$ & $\begin{array}{r}-0.361 \\
0.394\end{array}$ & $\begin{array}{l}-0.155 \\
0.678)\end{array}$ & $\begin{array}{l}0.236^{* * *} \\
0.0990\end{array}$ & $\begin{array}{r}-0.490 \\
0.374\end{array}$ & -0.00677 & $0.283 * * * *$ & $\begin{array}{r}-0.215 \\
-0.370)\end{array}$ & -0.0421 \\
\hline PM & $\begin{array}{l}-0.0739 \\
-0.157\end{array}$ & 0.452 & 0.154 & -0.114 & 0.598 & $\begin{array}{c}(1.351) \\
0.368\end{array}$ & $0.508^{* * *}$ & 0.297 & $\begin{array}{l}(0.04) \\
-0.485 \\
-(1463)\end{array}$ & $\begin{array}{l}-0.225 \\
-0.161\end{array}$ & $\begin{array}{r}0.445 \\
0.544\end{array}$ & $1.915 * *$ & $\begin{array}{l}-0.104 \\
0.57\end{array}$ & 0.633 & 1.270 & $\begin{array}{l}-0.115 \\
0.155\end{array}$ & 0.438 & 1.256 & -0.0828 & $\begin{array}{r}(0.37) \\
0.152 \\
0.544\end{array}$ & $\begin{array}{l}(0.641) \\
1.478^{*}\end{array}$ \\
\hline RES & $\begin{array}{c}(0.157) \\
0.448 * * *\end{array}$ & $\begin{array}{l}(0.590) \\
0.489 * \\
0.293\end{array}$ & $\begin{array}{c}(0.762) \\
0.466 \\
05089\end{array}$ & $\begin{array}{c}(0.160) \\
0.360^{* * * *}\end{array}$ & $\begin{array}{c}(0.540) \\
0.138 \\
(0.315\end{array}$ & $\begin{array}{c}(0.764) \\
0.413 \\
0.537\end{array}$ & $\begin{array}{c}(0.215) \\
0.393 * * *\end{array}$ & $\begin{array}{c}(0.742) \\
0.420 \\
(0.269)\end{array}$ & $\begin{array}{c}(1.463) \\
0.376 \\
0.541)\end{array}$ & $\begin{array}{c}(0.161) \\
0.399 * * *\end{array}$ & $\begin{array}{l}(0.544) \\
0.694 * * \\
0.3200\end{array}$ & $\begin{array}{c}(0.823) \\
0.772 \\
0.626\end{array}$ & $\begin{array}{c}(0.152) \\
0.552^{2 * * *}\end{array}$ & $\begin{array}{c}(0.505) \\
0.935 * * *\end{array}$ & $\begin{array}{c}(1.144) \\
0.185\end{array}$ & $\begin{array}{c}(0.155) \\
0.552^{* * * *}\end{array}$ & $\begin{array}{c}(0.522) \\
0.870^{* * * * *}\end{array}$ & $\begin{array}{c}(2.610) \\
0.399\end{array}$ & $\begin{array}{c}(0.157) \\
0.127\end{array}$ & $\begin{array}{c}(0.544) \\
0.636\end{array}$ & $\begin{array}{l}(0.848) \\
-0.725 \\
0.0741\end{array}$ \\
\hline CS*POL & $\begin{array}{l}(0.0704) \\
0.411 * * * \\
(0.151\end{array}$ & $\begin{array}{c}(0.293) \\
2.396 * * * \\
(0.680)\end{array}$ & $\begin{array}{l}(0.508) \\
1.551 * \\
0.858)\end{array}$ & $(0.0745)$ & $(0.315)$ & $(0.537)$ & $(0.0730)$ & $(0.269)$ & $(0.541)$ & $(0.0928)$ & $(0.300)$ & $(0.626)$ & $(0.0981)$ & $(0.337)$ & (1.170) & $(0.0969)$ & $(0.319)$ & (1.346) & $(0.164)$ & $(0.538)$ & $(0.874)$ \\
\hline $\mathrm{CS} * \mathrm{CR}$ & & & & $\begin{array}{l}-0.102 * * \\
(0.0415)\end{array}$ & $\begin{array}{l}0.00279 \\
(0.190)\end{array}$ & $\begin{array}{l}0.225 \\
(0254)\end{array}$ & & & & & & & & & & & & & & & \\
\hline $\mathrm{PM} * \mathrm{RL}$ & & & & & & & $\begin{array}{l}-0.467 * \\
(0.252)\end{array}$ & $\begin{array}{l}-0.335 \\
(1.022)\end{array}$ & $\begin{array}{l}-3.719 \\
(2.377)\end{array}$ & & & & & & & & & & & & \\
\hline RES*POL & & & & & & & & & & $\begin{array}{l}0.161 \\
(0.134)\end{array}$ & $\begin{array}{l}0.945 * * \\
(0.386)\end{array}$ & $\begin{array}{l}1.664 * * \\
(0.705)\end{array}$ & & & & & & & & & \\
\hline RES ${ }^{*} \mathrm{COR}$ & & & & & & & & & & & & & $\begin{array}{l}0.495 * * \\
(0.197)\end{array}$ & $\begin{array}{l}1.369 * * \\
(0.665)\end{array}$ & $\begin{array}{l}-0.0505 \\
(1.335)\end{array}$ & & & & & & \\
\hline RES*RL & & & & & & & & & & & & & & & & $\begin{array}{l}0.387 * * \\
(0.177)\end{array}$ & $\begin{array}{l}1.115^{*} \\
(0.600)\end{array}$ & $\begin{array}{c}0.709 \\
(1.796)\end{array}$ & & & \\
\hline RES*IS & & & & & & & & & & & & & & & & & & & $\begin{array}{l}0.0739^{*} \\
(0.0383)\end{array}$ & $\begin{array}{l}-0.0644 \\
(0.115)\end{array}$ & $\begin{array}{c}0.234 \\
(0.196)\end{array}$ \\
\hline Constant & $\begin{array}{l}-1.436 * * \\
(0.596)\end{array}$ & $\begin{array}{c}-7.023 * * * \\
(2.198)\end{array}$ & $\begin{array}{l}6.834 * * \\
(2.837)\end{array}$ & $\begin{array}{c}-1.825 * * * \\
(0.674)\end{array}$ & $\begin{array}{l}-6.049 * * \\
(2.649)\end{array}$ & $\begin{array}{l}7.859 * * \\
(3.622)\end{array}$ & $\begin{array}{l}-0.167 \\
(0.644)\end{array}$ & $\begin{array}{c}-5.362 * * * * \\
(2.026)\end{array}$ & $\begin{array}{l}8.164 * * \\
(3.658)\end{array}$ & $\begin{array}{l}-0.727 \\
(0.626)\end{array}$ & $\begin{array}{c}-6.143 * * * * \\
(1.831)\end{array}$ & $\begin{array}{l}1.611 \\
(3.603)\end{array}$ & $\begin{array}{r}-1.723 * * * * \\
(0.642)\end{array}$ & $\begin{array}{c}-7.864 * * * \\
(1.871)\end{array}$ & $\begin{array}{l}5.345 \\
(5.517)\end{array}$ & $\begin{array}{c}-1.721 * * * \\
(0.658)\end{array}$ & $\begin{array}{c}-7.134 * * * \\
(2.068)\end{array}$ & $\begin{array}{l}4.640 \\
(8.358)\end{array}$ & $\begin{array}{l}-0.658 \\
(0.694)\end{array}$ & $\begin{array}{c}-5.357 * * * \\
(1.983)\end{array}$ & $\begin{array}{l}6.933^{*} \\
(3.573)\end{array}$ \\
\hline Wald test & $120.34 * * * *$ & $20.80^{* * * *}$ & $76.07 * * *$ & $125.73 * * *$ & $23.11 * * *$ & $80.37^{* * * *}$ & $112.94 * * * *$ & $72.45 * * *$ & $67.69 * * * *$ & $100.50^{* * * *}$ & $67.08 * * * * 1)$ & $72.26 * * *$ & $\begin{array}{l}(26.26 * 2) * * \\
0\end{array}$ & $65.76 * * * *$ & $326.57 * * * *$ & 121.78 **** & $70.76 * * * *$ & $104.15 * * *$ & $124.30^{* * * * *}$ & $70.60^{* * * * *}$ & $66.88 * * *$ \\
\hline & 0.063 & 0.297 & 0.619 & 0.114 & 0.282 & 0.641 & 0.072 & 0.141 & 0.620 & 0.088 & 0.129 & 0.598 & 0.140 & 0.123 & 0.610 & 0.111 & 0.117 & 0.612 & 0.074 & 0.148 & 0.623 \\
\hline Hanse & 1 & 0.999 & 0.999 & 1 & 0.994 & 0.998 & 1 & 1 & 1 & 1 & 1 & 1 & 1 & 1 & 1 & 1 & 1 & 1 & 1 & 1 & 0.999 \\
\hline & Yes & $\mathrm{Ye}$ & $\mathrm{Yc}$ & $\mathrm{Ye}$ & $\mathrm{Y}$ & $\mathrm{Y}$ & $\mathrm{Yc}$ & $\mathrm{Yc}$ & $y_{0}-x_{0}$ & $\mathrm{Y}$ & $Y$ & Yes & Yes & $Y$ & $\mathrm{y}_{0}$ & & & & Yes & Yes & Yes \\
\hline & $\mathrm{Yc}$ & $\mathrm{Y}$ & $\mathrm{YS}$ & 1 & $\mathrm{Y}$ & 1 & Y & $r$ & $r$ & $\mathrm{Y}$ & $Y$ & 1 & 1 & $\mathrm{Y}$ & $\mathrm{Y}$ & $Y$ & & & & & Yes \\
\hline & $\mathrm{Y}$ & & & $Y$ & & & & $Y_{Y}$ & & & & & & & & & & & & & Yes \\
\hline & 4,689 & 4,687 & 4,689 & 4,689 & 4,687 & 4,689 & 4,689 & 4,687 & 4,689 & 4,689 & 4,68 & 4,689 & 4,689 & 4,687 & 4,6 & 4,689 & 4,687 & 4, & 4,689 & 4,687 & 4,689 \\
\hline & 736 & 736 & 73 & 73 & 736 & 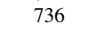 & 736 & 73 & 736 & 73 & 73 & 73 & 736 & 736 & 7 & 73 & 736 & 7 & 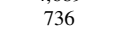 & 736 & 736 \\
\hline N. of banks & 1,052 & 1,052 & 1,052 & 1,052 & 1,052 & 1,052 & 1,052 & 1,052 & 1,052 & 1,052 & 1,052 & 1,052 & 1,052 & 1,052 & 1,052 & 1,052 & 1,052 & 1,052 & 1,052 & 1,052 & 1,052 \\
\hline
\end{tabular}

Notes: The table reports the results of the further analysis based on the disaggregation of z-score. Thus, the dependent variables are the three following: the negative of profit volatility (the negative of standard deviation of

ROA) is the -lnSDROA, the return on assets (ROA), and equity over total assets EQAS. POL is political stability, COR is control of corruption, RL is rule of law, CR is creditor rights, IS is information sharing, CS is capital regulation, RES is activities restrictions, PM is private monitoring. All models include the standard control variables and the individual institutional quality variables as in Tables 3 and 4 . The models that the dependent variable is EQAS do not include EQAS as a control variable. ***, ** and * indicate $1 \%, 5 \%$ and $10 \%$ significance levels respectively. Robust standard errors are in parentheses. 
Table 6. The Conditioning Effects of Institutional Quality on the Relationship between Bank Regulations and Bank Stability: Evidence from Alternative Institutional Quality Measures and Principal Component Analysis

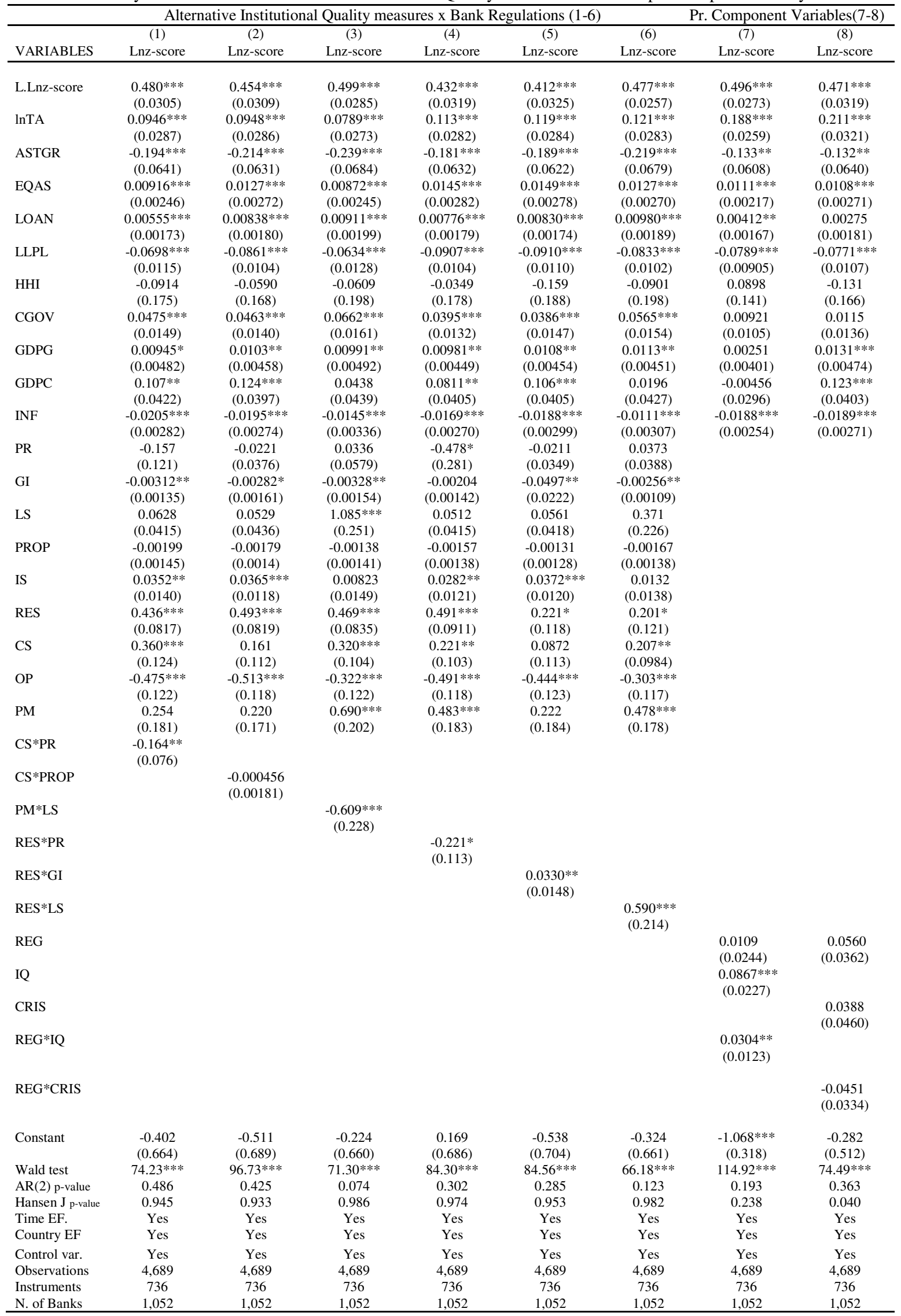

Notes: The models 1-6 of this table report the regression results of the impact of the interaction between the alternative institutional quality measures and bank regulations on bank stability over the period between 2004 and 2013 . The models 
7-8 of this table report the regression results using principal component analysis variables. In models 1-8, the dependent variables is the natural log of the Z-score (Lnz-score). lnTA is the natural logarithm of bank total assets, ASTGR is the growth rate of a bank's assets, EQAS is bank capitalization, LOAN is loans to total assets, LLPL is the loan loss provisions, HHI is the Herfinfahl-Hirschman Index for bank industry concentration based on loans, CGOV is corporate governance quality indicator, GDPG is GDP growth rate, GDPC is the natural logarithm of GDP per capita, INF is inflation rate, , CS is capital requirements regulation, OP is official supervisory power, RES is bank activities restrictions, PM is private monitoring, PR is political rights, PROP is the property rights, LS is the strength of legal structure, GI is the government integrity, IQ is the principal component of control of corruption (COR), political stability (POL) and the rule of law (RL), CRIS is the principal component of creditor rights CR) and information sharing (IS) and REG is the principal component of the four bank regulation and supervision variables (CS, OP, PM, RES).***, ** and * indicate $1 \%, 5 \%$ and $10 \%$ significance levels respectively. Robust standard errors are in parentheses. 
Table A1: List banks and observations by country

\begin{tabular}{|c|c|c|c|c|c|}
\hline Country & Banks & Obs & Country & Banks & Obs \\
\hline Algeria & 15 & 95 & Maldives & 1 & 4 \\
\hline Argentina & 69 & 628 & Mali & 5 & 7 \\
\hline Armenia & 15 & 133 & Malta & 7 & 19 \\
\hline Bangladesh & 26 & 75 & Mauritius & 14 & 53 \\
\hline Belarus & 21 & 143 & Montenegro & 8 & 35 \\
\hline Belize & 3 & 25 & Mozambique & 12 & 85 \\
\hline Benin & 7 & 33 & Namibia & 6 & 23 \\
\hline Bhutan & 3 & 13 & Nicaragua & 3 & 4 \\
\hline Bolivia & 9 & 13 & Niger & 5 & 29 \\
\hline Bosnia and Herzegovina & 24 & 94 & Pakistan & 27 & 97 \\
\hline Botswana & 7 & 29 & Panama & 44 & 163 \\
\hline Brazil & 87 & 323 & Peru & 6 & 26 \\
\hline Bulgaria & 24 & 195 & Philippines & 23 & 91 \\
\hline Burkina Faso & 9 & 42 & Rep. of Moldova & 14 & 52 \\
\hline Burundi & 4 & 20 & Romania & 25 & 105 \\
\hline Colombia & 23 & 90 & Russian Federation & 6 & 19 \\
\hline Cote D'Ivoire & 10 & 46 & Saint Lucia & 3 & 12 \\
\hline Dominica & 1 & 6 & Saint Vincent and the Grenadines & 1 & 3 \\
\hline Dominican Rep. & 41 & 149 & Senegal & 7 & 49 \\
\hline Egypt & 21 & 87 & Serbia & 26 & 100 \\
\hline El Salvador & 15 & 56 & Sierra Leone & 7 & 19 \\
\hline Ethiopia & 8 & 26 & Slovakia & 14 & 58 \\
\hline Ghana & 21 & 74 & South Africa & 13 & 52 \\
\hline Grenada & 2 & 14 & Sri Lanka & 16 & 46 \\
\hline Guatemala & 4 & 17 & Suriname & 4 & 14 \\
\hline Guyana & 3 & 27 & Thailand & 22 & 91 \\
\hline India & 56 & 227 & Togo & 4 & 25 \\
\hline Indonesia & 69 & 595 & Turkey & 29 & 108 \\
\hline Jamaica & 7 & 56 & Uganda & 15 & 58 \\
\hline Jordan & 11 & 59 & Uruguay & 39 & 344 \\
\hline Kenya & 28 & 113 & Vanuatu & 2 & 9 \\
\hline Kyrgyzstan & 6 & 32 & Venezuela & 32 & 127 \\
\hline Lebanon & 35 & 201 & Zimbabwe & 10 & 36 \\
\hline Macedonia, FYR & 12 & 84 & & & \\
\hline Malawi & 5 & 51 & & & \\
\hline Malaysia & 5 & 22 & & & \\
\hline
\end{tabular}




\begin{tabular}{|c|c|c|c|c|c|c|c|c|c|c|c|c|c|c|c|c|c|c|c|c|}
\hline & lnZscore & RES & $\mathrm{CS}$ & $\mathrm{OP}$ & $\mathrm{PM}$ & $\mathrm{POL}$ & CCOR & RL & $\mathrm{CR}$ & IS & $\ln \mathrm{TA}$ & EQAS & LOAN & LLPL & GDPG & GDPC & INF & CGOV & HHI & ASTGR \\
\hline lnZscore & 1 & & & & & & & & & & & & & & & & & & & \\
\hline RES & 0.05 & 1 & & & & & & & & & & & & & & & & & & \\
\hline CS & 0.14 & 0.26 & 1 & & & & & & & & & & & & & & & & & \\
\hline $\mathrm{OP}$ & 0.03 & 0.3 & 0.27 & 1 & & & & & & & & & & & & & & & & \\
\hline PM & -0.02 & 0.22 & 0.27 & 0.15 & 1 & & & & & & & & & & & & & & & \\
\hline POL & 0.21 & -0.26 & -0.34 & -0.12 & 0.03 & 1 & & & & & & & & & & & & & & \\
\hline COR & -0.12 & -0.13 & -0.16 & 0.1 & 0.24 & 0.65 & 1 & & & & & & & & & & & & & \\
\hline $\mathrm{RL}$ & 0.03 & -0.09 & -0.05 & 0.12 & 0.27 & 0.54 & 0.86 & 1 & & & & & & & & & & & & \\
\hline $\mathrm{CR}$ & 0.09 & 0.03 & 0.18 & 0.06 & 0.13 & 0.06 & 0.01 & 0.23 & 1 & & & & & & & & & & & \\
\hline IS & -0.05 & -0.22 & -0.1 & -0.07 & 0.25 & 0.27 & 0.27 & 0.21 & -0.08 & 1 & & & & & & & & & & \\
\hline $\ln \mathrm{TA}$ & 0.21 & 0.03 & 0.22 & 0.1 & 0.14 & -0.27 & 0.01 & 0.11 & 0.06 & 0.14 & 1 & & & & & & & & & \\
\hline EQAS & 0.01 & -0.09 & -0.14 & -0.02 & -0.04 & 0.12 & 0.03 & -0.03 & -0.06 & 0.06 & -0.48 & 1 & & & & & & & & \\
\hline LOAN & 0.1 & -0.06 & 0.06 & 0.06 & 0.03 & 0.05 & -0.02 & 0.05 & 0.22 & 0.09 & 0.09 & -0.14 & 1 & & & & & & & \\
\hline LLPL & -0.05 & -0.01 & -0.02 & -0.01 & 0.01 & 0.01 & 0.01 & -0.01 & -0.01 & 0.02 & 0.01 & 0.05 & -0.04 & 1 & & & & & & \\
\hline GDPG & 0.01 & 0.18 & 0.05 & -0.03 & 0.13 & -0.09 & -0.07 & -0.05 & -0.05 & -0.09 & -0.03 & -0.03 & -0.11 & 0.01 & 1 & & & & & \\
\hline GDPC & -0.04 & -0.29 & -0.2 & -0.02 & -0.1 & 0.4 & 0.46 & 0.33 & -0.21 & 0.6 & 0.13 & 0.09 & -0.05 & 0.01 & -0.18 & 1 & & & & \\
\hline INF & -0.21 & 0.14 & -0.12 & -0.07 & 0.03 & -0.01 & -0.16 & -0.35 & -0.22 & 0.12 & -0.06 & 0.07 & -0.14 & 0.01 & 0.05 & 0.11 & 1 & & & \\
\hline CGOV & 0.08 & -0.03 & 0.06 & 0.34 & 0.22 & 0.14 & 0.18 & 0.26 & 0.16 & 0.30 & 0.15 & -0.02 & 0.14 & 0.01 & -0.05 & 0.11 & -0.15 & 1 & & \\
\hline HHI & -0.06 & 0.02 & -0.11 & -0.05 & -0.21 & 0.15 & 0.14 & 0.10 & -0.12 & -0.30 & -0.15 & -0.01 & -0.11 & -0.01 & 0.02 & -0.14 & -0.01 & -0.28 & 1 & \\
\hline ASTGR & -0.09 & 0.04 & 0.05 & 0.15 & -0.05 & -0.03 & -0.01 & 0.02 & 0.02 & -0.07 & 0.15 & -0.13 & 0.09 & -0.02 & 0.07 & -0.04 & -0.20 & 0.08 & 0.03 & 1 \\
\hline
\end{tabular}


Figure A1: Theoretical model of how Institutional Quality could condition the effect of Capital Regulation, Private Monitoring, and Supervisory Power on Bank Stability

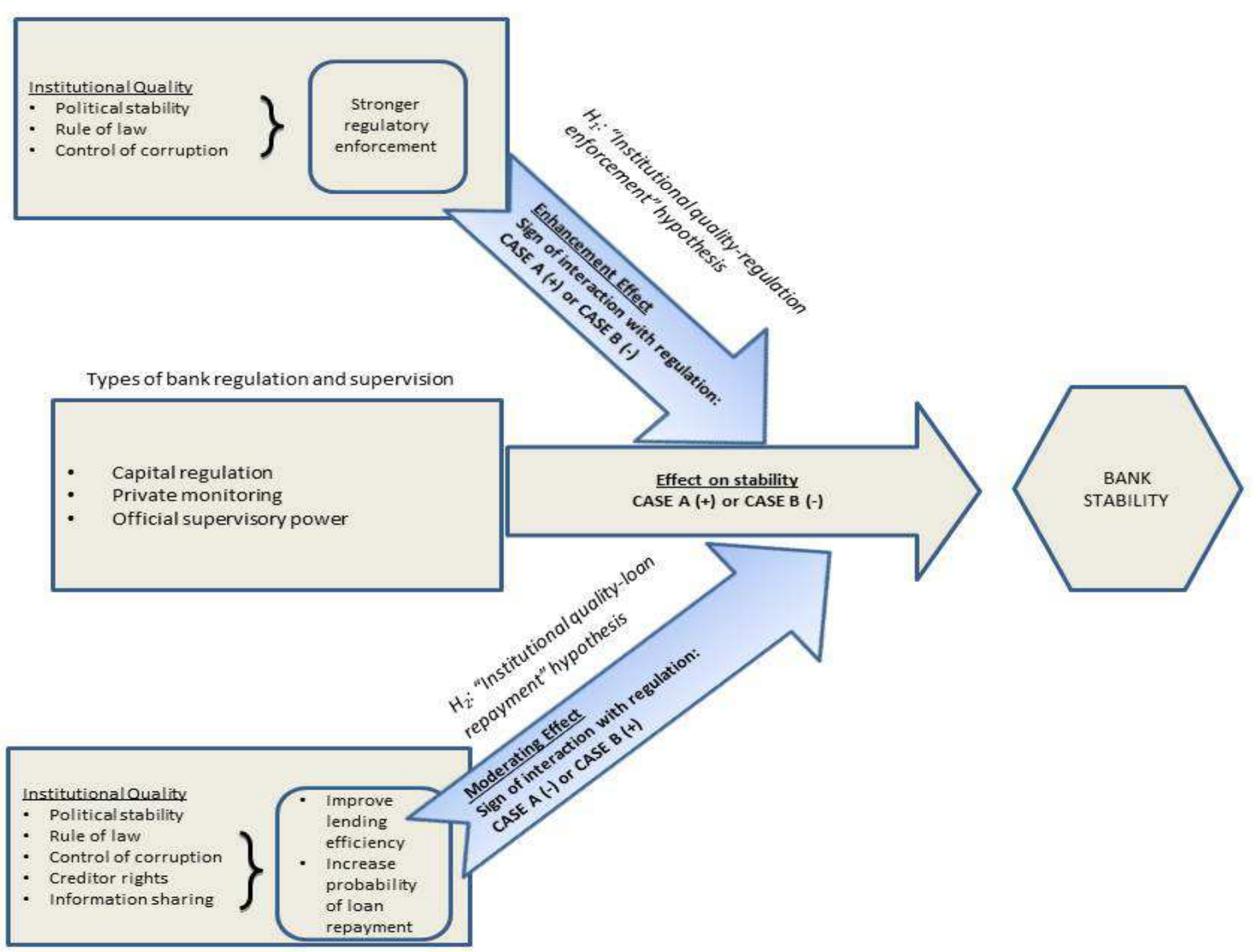


Figure A2: Theoretical model of how Institutional Quality could condition the effect of Activities Restrictions on Bank Stability

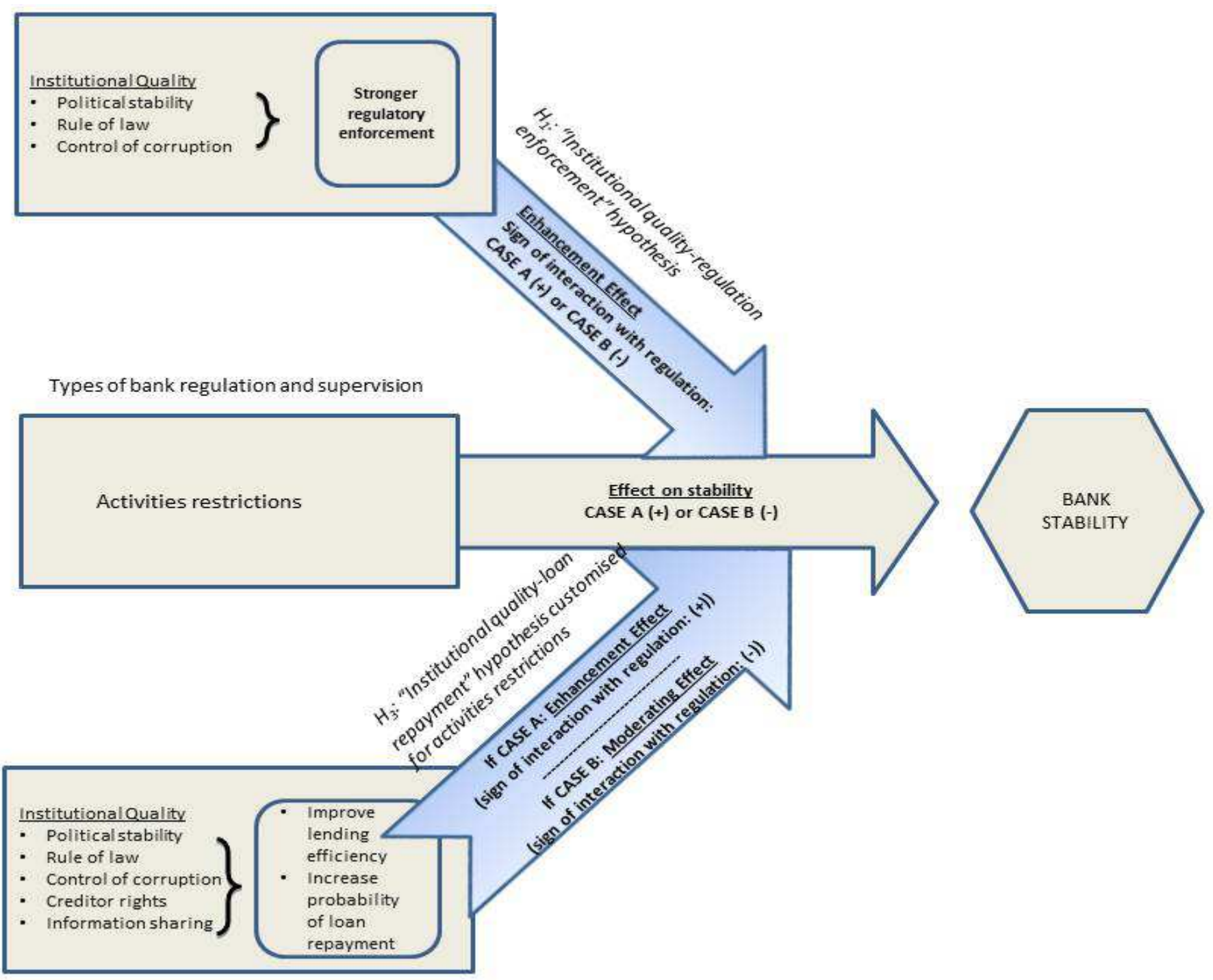

